\title{
To invest or not to invest? The roles of product information, attitudes towards finance and life variables in retail investor propensity to engage with financial products
}

Article

Accepted Version

Hillenbrand, C., Saraeva, A., Money, K. and Brooks, C. (2020) To invest or not to invest? The roles of product information, attitudes towards finance and life variables in retail investor propensity to engage with financial products. British Journal of Management, 31 (4). pp. 688-708. ISSN 1467-8551 doi: https://doi.org/10.1111/1467-8551.12348 Available at https://centaur.reading.ac.uk/81755/

It is advisable to refer to the publisher's version if you intend to cite from the work. See Guidance on citing.

To link to this article DOI: http://dx.doi.org/10.1111/1467-8551.12348

Publisher: Wiley

All outputs in CentAUR are protected by Intellectual Property Rights law, including copyright law. Copyright and IPR is retained by the creators or other copyright holders. Terms and conditions for use of this material are defined in the End User Agreement. 


\section{www.reading.ac.uk/centaur}

\section{CentAUR}

Central Archive at the University of Reading

Reading's research outputs online 


\title{
TO INVEST OR NOT TO INVEST?
}

The roles of product information, attitudes towards finance and life variables in retail investor propensity to engage with financial products

Carola Hillenbrand, The John Madejski Centre for Reputation, Henley Business School, University of Reading, Henley-on-Thames, RG9 3AU, UK. carola.hillenbrand@ henley.ac.uk

Anastasiya Saraeva, The John Madejski Centre for Reputation, Henley Business School, University of Reading, Henley-on-Thames, RG9 3AU, UK. anastasiya.saraeva@ henley.ac.uk

Kevin Money, The John Madejski Centre for Reputation, Henley Business School, University of Reading, Henley-on-Thames, RG9 3AU, UK. kevin.money@henley.ac.uk; Tel: +44 (0)1494 418833

Chris Brooks, The ICMA Centre, Henley Business School, University of Reading, Reading, RG6 6BA. c.brooks@icmacentre.ac.uk

\begin{abstract}
Little is known in the current literature about the factors affecting retail investor (RI) propensity to engage with financial products other than their attitude towards financial risk (ATFR). This study explores the role of a number of variables, thematically grouped into domain-specific (product information and attitudes towards finance) and general impact factors (life variables). Data from 970 UK-based RIs, collected in 2017 across a variant of products, suggest that when analysed thematically, variables related to product information emerge as the most important group of influence factors. While the relevance of ATFR is also vindicated in the findings of this study, the results bring a dose of life-context to situations of financial decision-making by illustrating that information about the product as well as life variables matter significantly, in particular negative emotions and sensation seeking - thereby highlighting a duty of care towards potentially vulnerable people. The study discusses implications arising from the findings in relation to research, practice and policy.
\end{abstract}

Key words: Retail investors, attitude towards risk, product information, emotions 


\section{BACKGROUND}

Financial decision-making by retail investors ${ }^{1}$ (RIs) in the UK is said to have become more important recently. For example, pensioners in the UK have options since 2014 to self-invest or spend in entirety their pensions. Yet the financial environment has also become ever more complex with an increasing array of potential investments to choose from (Bluethgen et al., 2008a, b; Hunt, Stewart and Zaliauskas, 2015). Financial advisors and institutions in the UK typically invite RIs to fill in a risk profiling questionnaire when inquiring about products. While this common practice is considered useful (Glenister 2014a, b; Simon 2016), far less is known to date about the relevance of other factors when RIs decide whether or not to engage with financial products. ${ }^{2}$ This is surprising given the significant role that choices concerning financial products can exert on citizens' lives, and has led to calls by the UK Financial Conduct Authority (FCA) to investigate the impact of other factors on RI behaviour such as product information and life variables ${ }^{3}$ (FCA, 2017).

Addressing such calls, this study aims to advance the current literature in two areas. First it builds on earlier scholarly work to specify and empirically test domain-specific impact factors relating to the investment context of RI decision-making as well as more general life-related impact factors (see for example, Grable, Britt and Webb, 2008; Weber, Blais and Betz, 2002). Second it includes cognitive and emotional aspects of these factors, as research in other contexts has highlighted the importance of both of these elements for human decision-making. However, studies combining them in the context of behavioural finance are scarce (Grable, 2017; Hoffmann and Ketteler, 2015; Kahneman and Tversky, 2013; Lerner et al. 2015; Lucey and Dowling, 2005; Weber, Blais and Betz, 2002).

Indeed, behavioural finance has gained a rapidly increasing prominence in recent years following the global financial crisis and related criticisms of existing paradigms based on 
unrealistic assumptions of rational investors. Recent research has highlighted the important role that emotions play in financial decision-making and that frameworks that explain behaviour must incorporate emotional and motivational effects (e.g., Loewenstein et al., 2001; Newell et al., 2007; Staddon, 2017).

We address this lacuna and explore the impact of both cognitive and emotional variables in the same study. We group variables thematically into two types of domain-specific impact factors: product information (including cognitive evaluations and judgements of credibility as well as positive and negative emotions towards product information) and attitudes towards finance/investment (including positive and negative emotions towards finance, attitudes towards financial risk and financial satisfaction). We also include more general life variables (including positive and negative emotions towards life, self-esteem and sensation-seeking), alongside a number of demographic variables such as income, net-worth, home-ownership, financial expertise and knowledge, gender and age.

Data from 970 UK-based RIs, collected in the summer of 2017 across a variant of products, suggest a vindication of ATFR measures as important predictors of RI intentions. Even when placed alongside other financial variables, the ATFR measure utilised emerges as the most important financially-based indicator.

Beyond ATFR, however, all four variables related to product information appear as significant impact factors. When analysed thematically, product information emerges as the most important group of indicators above and beyond attitudes towards finance/investment and life variables. While the other variables investigated in this study including ATFR may depend on unique personality characteristics and circumstances, product information contains a set of variables that can be influenced by service providers and regulated by industry bodies - and as such can provide an important tool for policy makers and practitioners to guide RIs responsibly. 
Perhaps most interestingly, however, negative emotions towards life and sensation-seeking are also found to impact upon RI decision-making. What is striking is that negative rather than positive emotions, as well as a predisposition for sensation-seeking - i.e., a tendency to search for intense sensations and a readiness to take extensive risks - be they physical, legal or financial, in the pursuit of such sensations - drive RIs to engage more readily with financial products. This finding highlights a duty of care among product providers and financial advisors towards potentially vulnerable people in relation to financial products and the communication thereof.

Overall, our findings support the usefulness of differentiating between variables relating to domain-specific and general impact factors, collaborate the importance of including both cognitive and emotional elements, and extend previous work by specifying and testing a number of such variables empirically. Methodologically, our approach outlines how predictor variables can be treated independently or can be systematically grouped into a hierarchical component model to analyse groups of impact factors thematically, and as such provide alternative avenues for future research. Furthermore, our findings lead to a number of managerial and policy implications, strongly linked to contemporary concerns around ethical banking, ongoing attempts by regulators to guide the investment industry responsibly and the work of many aiming to contribute to the sustainable financial lives of citizens (Cheah et al., 2011).

\section{HYPOTHESES DEVELOPMENT AND CONCEPTUAL MODEL}

Our hypotheses development builds on calls to research ATFR alongside other factors when aiming to understand RI intentions, most importantly calls to specify domain-specific and general impact factors and to include both cognitive and emotional elements (see for example FCA, 2017; Grable, 2000; Grable and Roszkowski, 2008; Grable, Britt, and Webb, 2008; 
Holler et al., 2008; Lerner and Keltner 2000; Lerner et al., 2015; Perry and Morris 2005; Zhou and Pham 2004).

Building on early work (see Irwin and Millstein 1986), Grable and Joo (2004) were among the first to argue that predisposing factors influencing investment behaviour can usefully be grouped into two sets: a person-related factor (referred to as a 'biopsychosocial' factor in their research) and a context factor (referred to as an 'environmental' factor in their research). Grable, Britt, and Webb (2008, p.6) then emphasise in particular the importance of the former group of factors which they believe "may hold the key to unlocking the triggers to financial risk-taking". Other scholars also stress the importance of personal characteristics and circumstances linked to individual propensities to take risks to explain why some individuals are more willing to do so than others (Adams and Jiang, 2017; Fagley and Miller, 1997; Weber and Milliman, 1997). Weber, Blais and Betz (2002) build on these advances and suggest that risk-taking behaviour may be driven by two groups of influences - general factors (i.e., linked to people's circumstances) and domain-specific factors (i.e., related to the risk-domain such as investment), both of which may include cognitive and emotional elements. While there is therefore a line of support for the conceptual separation of domain-specific and general impact factors, there is a lacuna of empirical work specifying and researching specific variables belonging to these two categories. The sections that follow first review the literature about relevant impact variables, before explicitly discussing the importance of emotional elements alongside cognitive elements and proposing a conceptual framework.

\section{Domain-specific impact factors}

In this study, we specify two domain-specific impact factors: product information and attitudes towards finance/investment. The latter factor builds and extends the use of ATFR as the primary indicator of RI behaviour, while with the former we follow increasing interest in 
understanding the role of information about financial products on RI intentions (FCA, 2017), with pioneering academic work by scholars such as Kahneman and Tversky $(1979,2013)$ illustrating that the framing of information and cognitive as well as emotional understanding thereof may significantly impact investment behaviour.

Product Information: The literature suggests that positive cognitive evaluation (such as finding it appealing or informative) of product information (e.g., a leaflet or ad) will positively influence intentions to engage with that product (Chaiken, 1980; Goldsmith, Lafferty and Newell, 2000; Kozup, Creyer and Burton, 2003; Lu, Chang and Chang, 2014; Petty, Cacioppo and Schumann, 1983). This effect has been confirmed across ads for familiar and unfamiliar products (Cox and Locander, 1987; Levin and Levin, 2010; Schuitema and Groot, 2015) as well as across different types of products (Hwang, Yoon and Park, 2011; Mehta and Purvis, 1997, 2006). Following MacKenzie and Lutz (1989, p. 49) we define product evaluation as "a disposition to respond in a favourable or unfavourable manner to particular product information during a particular exposure occasion". It seems reasonable to assume that positive evaluation of a financial product information will positively impact RI intention; however, the presence and extent of such an effect has to the best of our knowledge not been researched in the context of RIs, leading to hypothesis 1a.

Further to such evaluations, the credibility of product information, reflecting "the extent to which people believe the information" (Roberts, 2010, p. 45) is included as a relevant attribute of product information. The literature suggests a number of elements that are included in credibility assessments such as bias, believability and power to convince (Cotte, Coulter and Moore, 2005; Kim, Ratneshwar and Thorson, 2017; MacKenzie and Lutz, 1989). In terms of evaluating online message credibility, scholars such as Metzger et al. (2003) and Lowery (2004) include characteristics such as structure, intensity and evidence. Despite little 
verification from RI contexts, again it seems reasonable to assume that credibility judgements will also contribute to RI propensity to engage with financial products, leading to hypothesis $1 b$.

Hla: Positive evaluation of product information is positively associated with RI intention to engage with that product.

H1b: Credibility of product information is positively associated with RI intention to engage with that product.

Attitude towards finance/investment: As previously signalled, attitude towards financial risk (ATFR) is widely understood as a useful tool in the context of RI decision-making and is conceptually based on risk tolerance measures (e.g., MacCrimmon and Wehrung, 1984; Sung and Hanna, 1996; Weber, Blais and Betz, 2002; Yao, Hanna and Lindamood, 2004). Grable (2000, p. 625) defines financial risk tolerance as "the maximum amount of uncertainty that someone is willing to accept when making a financial decision" and proposes that risk tolerance affects almost every aspect of economic and social life. While the stark reliance on ATFR measures by the financial industry has recently been debated (Grable and Roszkowski, 2008; Slovic et al., 2004), it is commonly assumed that more risk-tolerant individuals are more likely to engage in a wide range of financial products than people with low risk tolerance scores (Grable, 2000; Grable and Joo, 2004; Grable, Britt, and Webb, 2008; Pålsson, 1996) - see hypothesis $2 \mathrm{a}$.

We include financial satisfaction as a further indicator of attitude towards finance/investment, based on empirical work by authors such as Grable and Roszkowski (2008) as well as Grable and Joo (2004) who call for further testing before clarity concerning its impact on RI can be reached. Financial satisfaction is defined as "a subjective evaluation of the degree to which one's financial resources are adequate versus inadequate, or satisfactory versus unsatisfactory" 
(Hira and Mugenda, 1998, p. 76). Financial satisfaction has received attention in studies related to individual well-being as well as in studies on financial risk taking (Grable, Britt, and Webb, 2008; Netemeyer et al., 2017; Porter and Garman, 1993; Robb and Woodyard, 2011; Sahi, 2017), based on which the authors argue that financial satisfaction will lead RIs to engage more readily with financial products, see hypothesis $2 b$.

H2a: A highly tolerant ATFR score is positively associated with RI intention to engage with financial products.

H2b: Financial satisfaction is positively associated with RI intention to engage with financial products.

\section{General impact factor}

The general impact factor included in this study is labelled 'life variables' to signal that the variables chosen relate to personality influences and personal circumstances of RIs. This builds on, and further tests, the pioneering work of Grable et al. (2008) and also responds to calls by bodies such as the FCA to better understand what factors unrelated to the financial context may impact RIs most strongly. We focus on two such variables that emerge from the current literature as very important in this context, namely self-esteem and sensation-seeking, while acknowledging that future work could usefully include a wider range of life variables.

Life variables: Self-esteem is suggested as a life variable that can play an important role in financial situations (Farrell, Fry and Risse, 2016; Grable and Joo, 2004; Krueger and Dickson, 1994; Tang and Baker, 2016). Following Grable, Britt, and Webb (2008, p. 8), self-esteem is defined as "a subjective evaluation based on feedback received from others concerning behaviour, appearance, and other personal traits". Overall, self-esteem is found to be positively related to risk perceptions (see Arch, 1993; Grable and Joo, 2004; Judge et al., 1999; Montford 
and Goldsmith, 2016). However, Krueger and Dickson (1994) argue that the effects of selfesteem significantly depend on whether individuals view a situation as an opportunity or a threat (having a positive and negative relationship with self-esteem respectively). As financial products are typically portrayed as opportunities rather than threats, we propose that high selfesteem will lead RIs to engage with financial products more readily - see hypothesis $3 \mathrm{a}$.

A further life-variable that is particularly relevant to the context of this study is sensation seeking (Mishra and Novakowski, 2016; Wong and Carducci, 1991, 2016), defined as "the need for varied, novel, and complex sensation and experiences and the willingness to take physical and social risks for the sake of such experiences" (Zuckerman, 1979, p. 10). While there is ample evidence for a link between sensation-seeking and risk-taking, driven by a need for arousal and stimulation (Grable and Joo, 2004; Wong and Carducci, 1991), studies are typically situated in gambling and game of chance scenarios (Wong and Carducci, 1991; Lauriola et al., 2014). To our knowledge, studies linking sensation-seeking with RI are missing. However, one may expect that sensation seekers are more likely to take risks in financial matters and as such may be more likely to engage with investment products generally, see hypothesis $3 b$.

H3a: Self-esteem is positively associated with RI intention to engage with financial products.

H3b: Sensation seeking is positively associated with RI intention to engage with financial products.

\section{The importance of emotions}

Within the behavioural finance literature, there is already evidence that people often deviate from rational models of decision-making, particularly in situations of ambiguity such as investment scenarios (Epstein, 1994; Kahneman and Tversky, 2013; Slovic et al., 2004; 
Schunk and Betsch 2006; Wang, 2006). Importantly, the impact of emotions has been identified as one possible explanation for this well-established effect (Chou, Lee, and Ho, 2007; Fehr et al., 2007; Lerner et al., 2015; Williams 2004; Yuen and Lee, 2003). For example, Wright and Bower (1992) suggest that happy and optimistic individuals are more likely to engage in risky events than sad people. Interestingly, Sizer (2000) proposes that positive emotional states are associated with wider information search, and as a consequence people are less likely to concentrate on the details of a risky event. Being of a nervous disposition may lead to the selection of lower risk investments and withdrawal from the markets when faced with a downturn (Smith and Ellsworth, 1985). Relatedly, it has been shown that fear prevents people from taking risks while anger encourages it (Ellsworth and Scherer, 2003; Gambetti and Giusberti, 2012; Habib et al., 2015; Kuppens et al., 2003). According to Loomes and Sugden (1982) and Michenaud and Solnik (2008), regret, and in particular the anticipation of future regret, can also have a profound impact on financial decision-making, leading to sub-optimal outcomes and to investors refusing to invest in stocks despite their superior risk-adjusted performance (Barberis, Huang and Thaler, 2006).

The impact of emotions can also potentially explain other apparently anomalous results in investing behaviour. For example, older people are often less financially risk tolerant than the young (Brooks et al., 2018), and this may be related to a decline in cognitive abilities leading emotional states to have an enhanced role in financial choices (Rypma et al., 2001). A diminished emotional robustness leads older people to be more likely to take fright and sell risky assets at the worst point in the financial market cycle (Browning and Finke, 2015; Friesen and Sapp, 2007). Similarly, women are less likely to make risky investments than men (Brooks et al., 2017) and there is a voluminous literature suggesting that the former worry more (e.g., McCann, Stewin and Short, 1991; Ricciardi, 2008), are more fearful of negative outcomes 
(Fujita, Diener and Sandvik, 1991), and are more likely to have an internal locus of control blaming themselves when things go wrong (Craske, 2003).

As the examples above demonstrate, scholars seem to focus on risk tolerance and its link with general life emotions (such as happy, sad, fearful), whereas little is known about how these findings may relate to RI intention to engage with financial products and how emotions specifically felt in the context of finance/investment and/or specifically towards financial product information complement emotions towards life more generally. Furthermore, while there is merit in investigating the role of specific emotions, such as anger, fear or happiness, as often achieved in the studies above, emotions can also usefully be understood as "the felt tendency toward anything intuitively appraised as good (beneficial), or away from anything intuitively appraised as bad (harmful)" (Arnold, 1960, p. 182 - see also Nguyen and Noussair, 2014; Schulreich, Gerhardt and Heekeren, 2016; Wang et al., 2014). In fact, scholars such as Izard $(1977 ; 2013)$ and Watson and Tellegen (1985) suggest that emotions may fall into two broad categories: positive and negative, and that much can be learned by investigating and comparing the impact of positive and negative emotions across situations (Ashkanasy, Humphrey and Huy, 2017; Cooper et al., 1995; Fredrickson, 1998; Griffiths, 2008; Henle and Gross, 2014). As a means to research positive and negative emotions across a number of contexts, we draw on Watson, Clark and Tellegen (1988) (later Watson and Clark 1994; Watson et al., 1999), who suggest positive and negative affect as two dominant, independent dimensions of individual moods and offer the Positive and Negative Affect Scale (PANAS) as means of measurement.

Taking account of this widely utilised notion of emotions as broadly positive or negative, we acknowledge the suggested importance of positive/negative emotions as impacting human decision-making across contexts and in relation to specific as well as general life situations 
(Lerner et al., 2015). We thus include the role of both positive and negative emotions in our hypotheses development, but separately, in relation to all three themes in this study - i.e., product information (see H1c, H1d), attitude to finance (see H2c, H2d) and life (see H3c, H3d): H1c: Positive emotions towards product information are positively associated with RI intention to engage with financial products.

HId: Negative emotions towards product information are negatively associated with RI intention to engage with financial products.

H2c: Positive emotions towards finance are positively associated with RI intention to engage with financial products.

H2d: Negative emotions towards finance are negatively associated with RI intention to engage with financial products.

H3c: Positive emotions towards life are positively associated with RI intention to engage with financial products.

H3d: Negative emotions towards life are negatively associated with RI intention to engage with financial products.

\section{CONCEPTUAL FRAMEWORK}

We present a conceptual framework that incorporates the relationships proposed in H1a-d, $\mathrm{H} 2 \mathrm{a}-\mathrm{d}$ and H3a-d, before discussing how the framework can be analysed in two related ways, given the early stage of theory in this arena and the need for more exploratory-type research: by examining the role and impact of each individual variable (i.e. to investigate separately the 
impact of emotional and cognitive elements), as well as by looking at the joint impact of variables grouped into the three themes analysed in a hierarchical component model (in order to look at the broader impact of domain-specific and general factors at their summary level). See figure 1 below for a graphical summary of the conceptual relationships proposed in our research hypotheses.

\section{[INSERT FIGURE 1 ABOUT HERE]}

Table 1 illustrates that for the hierarchical component model, all individual variables are considered first order constructs, while their themes are considered second-order constructs.

\section{[INSERT TABLE 1 HERE]}

Scholars suggest that the use of higher-order constructs (HOCs) can provide a robust way to increase theoretical parsimony and reduce model complexity (Edwards, 2001; Law, Wong and Mobley, 1998; MacKenzie, Podsakoff and Jarvis, 2005) but they require conceptual as well as methodological/empirical justification (Hair et al., 2016, 2018). While a detailed methodological/empirical justification is provided below, a brief discussion of our conceptual positioning follows here.

As previously outlined, scholars hint at the existence of HOCs in relation to RI intention, but do not empirically test such claims. However, Sivaramakrishnan, Srivastava and Rastogi, (2017) operationalise a HOC 'attitude toward investment behaviour', including three lowerorder constructs (LOCs): risk avoidance; hassle factor, and the perception of regulators. In the area of emotions. Tronvoll (2011) expands the notion of a higher-order emotional construct by Watson and Clark (1994) and models negative emotions towards life as a HOC consisting of five first-order emotions. Hence the existing evidence on the use of HOCs in the related literature indicates the usefulness of such a conceptual approach and the use of HOCs in 
management and business studies is increasingly popular for conceptual coherence and structure (Doll, Xia and Torkzadeh, 1994; Edwards, 2001; Hair et al., 2012; Jarvis, MacKenzie and Podsakoff, 2003; Kuppelwieser and Sarstedt, 2014; Wetzels, Odekerken-Schröder and van Oppen, 2009).

\section{METHODOLOGY}

\section{Study context, procedure and sampling}

The context of this study is retail investors (RIs) and their propensity to engage with financial products. UK RIs were recruited in June 2017 to take part in an online survey that lasted 10 minutes. The survey was hosted on Qualtrics online platform, and they recruited participants in line with their standard remuneration practices according to a defined set of sampling criteria that was a priori decided by the researchers. The sampling frame was based on a random sampling procedure of UK residents and involved a number of quotas to ensure an appropriate split between gender, age, income and RI investment experience. Participants were informed that they would be asked a range of questions, that they would be exposed to a leaflet about a new financial product and that they were encouraged to carefully study the leaflet as they would be asked about it later (an example leaflet can be found in Appendix 1). To avoid any bias towards existing financial firms, advisors or products, all information was created specifically for this study.

The content and design of the leaflet was based on extensive research on how investment firms advertise their products. Typically, a leaflet contains a single page with detailed specifications of a financial product. In consulting with experts in the field of investment, we developed a leaflet which advertised an investment portfolio with a range of actual market specifications (i.e., selection of investments, time horizon, terms and conditions). The product information was varied systematically to ensure that the data collected was relevant irrespective of the 
specific product, and that any findings and conclusions held across different types of product information. The variation of information related to the length of time for investment in a product, the level of return, and whether the product could be described as an income or growth portfolio. The financial service company offering the products was fictitious (named 'DeltaInvest'), and this was revealed to participants at the end of the survey. The study was subjected to standard University ethics screening and given the green light to proceed.

\section{Measures}

Measures of attitudes towards finance/investment and life variables were mostly placed in the first part of the survey to ensure that answers were not informed by the specific information respondents later received about the product. Measures of product information were situated after the product leaflet had been shown as these questions required an actual product to assess. In addition, a set of questions relating to RIs' propensity to engage with the financial product that they had seen were asked post-product leaflet. These items act as dependent measures in our study. ${ }^{4}$ To ensure that participants were able to understand all questions and to fill them in confidently, all measures were pre-tested and piloted with RIs. A list of items that was included in the analysis after reliability and validity procedures were performed can be found in Appendix 5.

All independent constructs are measured using scale items derived from previously published and peer-reviewed research, with the exception of the AFTR, which is not currently published but is an industry-relevant measure widely in use in the UK, developed by Distribution Technology. It includes questions such as: "Compared to the average person, I take lower financial risks"; “Taking financial risks is important to me”. Measures of positive and negative emotions towards variables in all three themes were adapted from the PANAS scale developed by Watson, Clark and Tellegen (1988). Measures of sensation seeking (Arnett, 1994), self- 
esteem (Rosenberg, 1965), and financial satisfaction measures were adapted from Grable and Joo (2004). Evaluations and judgments of the credibility of the leaflet are based on Baker and Churchill (1977) and Flanagin and Metzger (2000). The dependent variable (intention to engage) was developed specifically for the purposes of this study, based on how similar intention measures are operationalised in the literature (see, for example, Boulding et al., 1993; Helm, 2007; Sen, Bhattacharya and Korschun, 2006), including whether individuals would be “(...) interested to invest in the portfolio offered" and would "(...) recommend this portfolio to friends/family”. Both independent and dependent constructs utilised five-point Likert-type scales.

\section{Common method bias}

Two statistical procedures suggest the likelihood of common method bias to be low. Harman's single factor test shows that, in an un-rotated factor analysis, $19.4 \%$ of variance is explained by one factor (Harman, 1976). The Lindell and Whitney (2001) test was applied using one manipulation check item as a marker, showing no significant correlation between the marker item and model constructs.

\section{First- and second-order constructs}

Methodologically, it is advisable to reduce the number of established path relationships in structural equation modelling (Hair et al., 2016). Our conceptual framework involves twelve LOCs, indicating high model complexity (Hair et al., 2018). Thus, HOCs can allow the development of a more parsimonious model. In addition to establishing the relationships between LOCs and HOCs, it is critical to specify the type of hierarchical component model (Jarvis, MacKenzie ad Podsakoff, 2003; Hair et al., 2018). Following Hair et al. (2018), a Type II Reflective-Formative model appears to fit the purpose of the present study particularly well. ${ }^{5}$ 


\section{Data preparation and analysis}

The data were entered into SPSS Statistics 24 in order to assess missing values ${ }^{6}$ and outliers as well as distributional properties. This initial stage of data preparation led to the exclusion of 180 straight-liners ${ }^{7}$ and 15 outliers, which led to a final sample of 970 - see Table 2 for sample demographics. ${ }^{8}$ A small proportion of data was found to violate the assumption of normality. Due to this and the high complexity of the model proposed, we adopted a partial least squares structural equation modelling (PLS-SEM) approach for the initial assessment of the conceptual model with all 12 indicator variables (Chin, 2010; Hair et al., 2012), ${ }^{9}$ in line with other recent business and management literature (Ahammad et al., 2017; Braun et al., 2018; Nair et al., 2018; West et al., 2016) and finance-related studies (Hegner-Kakar, Richter and Ringle, 2018; Moneva and Ortas, 2010; Nitzl, 2016; Pew Tan, Plowman and Hancock, 2006; Ramli, Latan and Nartea, 2018).

\section{[INSERT TABLE 2 ABOUT HERE]}

Data analysis is structured in three stages.

Stage 1: A two-stage analysis of the full conceptual model was performed (Hair et al., 2016). The first step involves an assessment of reliability and validity of the measurement model. ${ }^{10}$ The second step involves an assessment of the structural model, including estimation of the paths within the model (sign, magnitude and significance, obtained through bootstrapping procedure); the coefficient of determination $R^{2}$; the effect size $f^{2}$ of predictor variables; crossvalidated redundancy $Q^{2}$ (predictive relevance) and the effect size $q^{2}$ (using a blindfolding procedure) (Henseler and Sarstedt, 2013; Hair et al., 2014). To test for differences in control variables, we used Multi Group Analysis (MGA) within PLS-SEM (Sarstedt, Henseler and Ringle, 2011). 
Stage 2: The analysis controls for the impact of demographic variables such as income, networth, home-ownership, financial expertise and knowledge, gender and age on the full conceptual model.

Stage 3: Finally, we use the repeated indicator approach by Lohmöller (1989), which is most suitable for the analysis of the Type II hierarchical component model. To assess the model, we then use a factor weighting scheme with Mode B (Becker, Klein and Wetzels, 2012; Hair et al., 2018), and evaluate collinearity statistics using the VIF scores of the higher-order constructs (Hair et al., 2016, 2018).

\section{RESULTS}

\section{Stage 1: Assessment of the conceptual model with 12 predictor variables}

Composite reliability scores reveal satisfactory levels for all constructs from 0.750 to 0.956 (Hair et al., 2016). AVE scores are all above the suggested threshold of 0.5 and discriminant validity is deemed satisfactory as the Fornell-Larcker criterion confirms that the square root of the AVE for each endogenous variable is higher than the variance shared by any other construct (see Appendix 2). Likewise, an assessment of cross-loadings demonstrates that loadings for indicators associated with a specific construct are higher than for any other construct within the model.

Bootstrapping of the full structural model reveals seven of twelve hypothesized paths to be significant at the level of $p<0.01$, with varying magnitude: All paths related to product information are significant. In particular, positive and negative emotions towards product information predict RIs' intentions with $\beta=0.378 \quad(p<0.001)$, and $\beta=-0.079 \quad(p<0.003)$ respectively. Product information credibility has a positive impact on intentions $(\beta=0.089$, $p<0.04)$ as well as RI evaluation of product information $(\beta=0.252, p<0.001)$. Furthermore, 
ATFR is positively related to RIs intentions with a path of $\beta=0.234, p<0.001$. In terms of life variables, two paths are found to significantly predict RI intentions: negative emotions towards life $(\beta=0.097, p<0.02)$ and sensation seeking $(\beta=0.083, p<0.01)$.

The coefficient of determination for the dependent variable is moderate to large $\left(R^{2}=0.564\right.$; $R^{2}$ adj=0.559), effect sizes $f^{2}$ for predictor variables of endogenous constructs range between small to moderate (0.002 to 0.116) (Chin, 1998). Blindfolding is applied to evaluate StoneGeisser's $Q^{2}$ value (Geisser, 1974; Stone, 1974). The results confirm the predictive relevance of all exogenous constructs on their related endogenous construct $\left(Q^{2}=0.373\right)$. Table 3 summarises the results in relation to all hypotheses.

\section{[INSERT TABLE 3 ABOUT HERE]}

\section{Stage 2: Control variables}

The analysis of control variables considers demographic information such as gender, age, income, net-worth and home-ownership first (see Appendix 3), before examining financerelated control variables measuring financial expertise and knowledge (see Appendix 4). Only differences relating to significant paths within the full conceptual model are summarised for parsimony in Table 4 below.

\section{[INSERT TABLE 4 ABOUT HERE]}

\section{Stage 3: Hierarchical component modelling}

The measurement model for LOCs was found to be generally consistent with the above analysis of the assessment of individual variables in stage 1 (see analysis of hypotheses 1a-d, 2a-d, 3ad) and is thus not reported again. The assessment of the HOC measurement model demonstrates VIF estimates not exceeding the suggested threshold of 5 (see Hair et al., 2018). 
Table 5 presents the structural model evaluation, utilizing standard bootstrapping to evaluate significance of LOCs weights in relation to HOCs as well as path relationships between HOCs and the outcome construct. The assessment shows that eleven weights between LOCs and HOCs as well as all path relationships between HOCs and the outcome variable are significant, with varying magnitude: for product information (HOC), the LOCs positive emotions and evaluation of product information have the largest weights of 0.414 and $0.384, p<0.001$. Within attitudes towards finance/investment (HOC), the LOC's positive emotions towards finance and ATFR are found to have the largest relevance of 0.420 and $0.417, p<0.001$. Within life variables, all LOCs have significant relevance, while self-esteem and positive emotions towards life have the largest individual weights of 0.383 and $0.372, p<0.001$, respectively.

\section{[INSERT TABLE 5 ABOUT HERE]}

In summary, the three HOCs are found to all significantly predict RI intentions. In particular, HOC product information holds the strongest single impact on RI engagement with the financial product $(\beta=0.616, p<0.001)$, followed by attitudes towards finance/investment $(\beta=0.219, p<0.001)$, and life variables $(\beta=-0.081, p<0.05)$. The coefficient of determination of the dependent variable is moderate to large $\left(R^{2}=0.519 ; R_{\text {adj }}^{2}=0.517\right)$, the effect sizes $f^{2}$ of HOCs on the endogenous construct ranges between small (for life variables and attitudes towards finance/investment), and large (product information): $0.01,0.06$, and 0.575 respectively.

\section{DISCUSSION}

Product information emerges from the findings of this study as exerting a strong impact on RIs. As product information can be controlled by investment firms, its role and impact need to be considered when communicating information about products with varying degrees of 
complexity, risk and attraction. Interestingly, the ATFR measure emerges as the only financially-based indicator with a significant result in Table 3 and is also found in the subsequent thematic analysis to have among the largest relevance in forming its respective higher-order construct. As such, the importance of risk attitude, which is discussed extensively in the literature and widely measured in practice, is confirmed in the empirical results of this study $^{11}$ (Grable, Britt, and Webb, 2008). Our findings suggest that beyond product information and ATFR, negative emotions towards life and sensation-seeking also impact RI propensity to engage with financial products. Both of these life variables highlight a duty of care towards potentially vulnerable people in relation to financial products and communication thereof, i.e. in cases in which investors with strong negative emotions or a high tendency for sensation seeking may engage with products and levels of risks that are not beneficial or appropriate given their financial circumstances (Delgado-García et al., 2010; Kooij-de Bode et al. 2010).

\section{Insights from control variables}

The analysis of control variables reveals a very consistent pattern: most differences between control groups related to age, gender, income, net-worth, home-ownership and financial expertise/knowledge emerge between RI positive and negative emotions towards the variables investigated: positive emotions in general seem to impact more on the intentions of male participants, high-income participants, high net-worth individuals and on participants with more knowledge or more experience. At the same time, the impact of negative emotions is stronger felt by female participants, non-home-owners and less knowledgeable or experienced individuals. This is particularly the case for emotions towards finance/investment and emotions towards product information but is also found in variables related to general emotions towards life. $^{12}$ 
An interesting pattern of results emerges in relation to age: while older participants react strongly and negatively to negative emotions towards product information (i.e., if older participants do not like the product information they more significantly dis-engage), they also do not engage more readily as a function of positive emotions towards life generally (contrary to the findings reported above). Younger participants, on the other hand, react particularly strongly and positively as a function of sensation seeking and of low self-esteem, but positive emotions towards finance/investment do not make them engage more readily (contrary to the findings reported above). This suggests that product information needs to be tailored very specifically to an older age group and that younger participants feel the impact of selfconfidence, or lack thereof, particularly strongly (resonant of Grable, Britt, and Webb, 2008).

Finally, the impact of ATFR on RI intention to engage differs significantly between investors with more and less investment experience: high ATFR scores impact less experienced investors more than experienced investors, perhaps suggesting that risk tolerance may not be a function of experience but of personality - a suggestion further supported by the finding that the impact of ATFR does not vary with financial knowledge as a control variable.

\section{Conceptual implications}

Our findings support calls for a conceptual separation (of domain-specific and general impact factors), and a conceptual inclusion (of emotional and cognitive elements) and suggest a range of useful variables to include in future work. In particular with regard to domain-specific factors, our findings suggest that the way in which financial information is portrayed matters to RIs, and as such characteristics of communications need conceptual attention in economic contexts (Ahlers et al., 2017; Ewe et al., 2018; Hauff et al., 2016; Holler et al., 2008; Lerner et al., 2015; Meyerowitz \& Chaiken, 1987). 
Furthermore, our findings indicate there may be merit in studying a wider set of personality and life variables. While the role and importance of ATFR measures is vindicated in the findings of this study, it is unclear to what extent risk measures may correlate with life variables and personality factors such as sensation seeking and negative life emotions. Hence, encouraging individuals with high risk tolerance scores to take out more risky products, as may currently be seen as good practice (Corter and Chen, 2006; Croy, Gerrans and Speelman, 2010; Grable, Britt, and Webb, 2008; Seetharaman et al., 2017), may be less appropriate than commonly thought and in need of research for confounding effects.

A further conceptual implication relates to the possibility of understanding predictor variables either as isolated factors and/or to conceptualise them as grouped into themes. While our choice of themes was strongly guided by suggestions in the literature (Farrell, Fry and Risse, 2016; Grable et al. 2008; Grable and Joo, 2004; Irwin and Millstein, 1986; Wang, 2006; Weber, Blais and Betz, 2002), we by no means suggest that we have identified a comprehensive list. However, we are confident that the idea of grouping variables into themes conceptually as well as methodologically may be useful: in particular, the HCM analysis applied in this study suggests that themes of influence factors may present a feasible and useful way forward - not only to understand the impact of individual elements within factors, but also the overriding importance of themes relative to each other.

\section{Managerial implications}

Managerially, our finding suggests the consideration of a range of variables in addition to ATFR for managers to handle relationships with clients meaningfully. Resonant of the marketing and advertisement literatures (Brown, Homer and Inman, 1998; Derbaix, 1995; Morris et al., 2002), as well as the literature on customer (dis)engagement (Dubé and Menon, 2000; Liljander and Strandvik, 1997; Phillips and Baumgartner, 2002; Voorhees, Brady and 
Horowitz, 2006), the extent to which information is understood, liked and believed is found here to predict engagement.

Currently, some financial service providers are looking to launch online investment advice services (so-called 'robo-advisors') (J.P.Morgan Investment Trust Team, 2017; Wright et al., 2016), offering a cheaper wealth management service to those with lower savings (Simon, 2016). However, the results of this study suggest that there are complexities and person-specific variables that would usefully be considered when advising RIs individually, contrary to technology-enabled algorithms, requiring a more in-depth and personalized understanding of circumstances.

Furthermore, for financial advisors and institutions that want to operate responsibly, the results of this study offer suggestions on how to be mindful of the implications arising from the demographics of clients and their associated preferences and biases, as well as mindful of general life and personality factors. In particular, the findings suggest putting managerial measures in place to protect customers with negative life emotions (perhaps due to significant life events) and people who seem overly excited about risk (i.e., sensation seekers).

\section{Policy implications}

Policy makers, as well as service providers, have a duty of care towards RIs. Following the 2008 recession, the UK government, alongside those of other countries, has sought ways to regulate the financial services industry more and to protect consumer and societal interest going forward. UK-based figures, however, suggest that money advice services are having to deal with increasing numbers of personal financial crises, amid annual rises in consumer credit and escalating debt. ${ }^{13}$ 
Indeed, work conducted by the FCA reveals that about $50 \%$ of the UK population is potentially vulnerable due to low financial resilience, low financial capability or adverse life events. $24 \%$ of UK adults have little or no confidence in managing their money and $46 \%$ of UK adults report low knowledge about financial matters (FCA, 2017). Policy makers could use the findings of this study to advise financial service providers to routinely assess personal circumstances as well as the impact of product information on vulnerable consumer groups alongside ATFR assessments, with a view to tailoring products more appropriately to individual contexts and life variables.

From a policy perspective, it may also be noteworthy that the results of our study suggest combining insights from what the firm/product has to offer (summarised in product information) with characteristics of individual investors (such as attitude towards finance and life variables) (Corter and Chen, 2006; Croy, Gerrans and Speelman, 2011). Rather than working with financial service providers and RIs separately, policy makers could encourage both groups to share concerns and work on suitable solutions and the communication thereof jointly. Interestingly, only four in ten UK adults have confidence in the financial services industry, and at least 1.3 million UK adults claim to have experienced mis-selling from an advisor at some point (FCA, 2017). These figures highlight the need for trust-building exercises and better communication between both parties, a process that could be facilitated and encouraged by policy makers along the lines of the variables explored in this study.

\section{LIMITATIONS AND FUTURE RESEARCH}

A limitation of this study relates to the cross-sectional nature of data collection. As indicated earlier, data for this research were collected in the midst of Brexit negotiations and uncertainty, and it is not clear from the findings of this study how this ambiguity may impact RI intentions. 
This could be usefully addressed through a longitudinal study that incorporates variables related to political and other externalities and their impact on RIs' behaviour (J.P.Morgan Investment Trust Team, 2017). Furthermore, it would be useful to compare our findings with the actual investment behaviour of RIs following their exposure of financial products, as well as the long-term satisfaction and implications derived from actual investment decisions.

Due to the exploratory nature of this study, we were not able to hypothesize and test a range of potential moderating effects. For example, some RIs may be willing to consider risky investment products for primarily emotional reasons (for example, the excitement of 'playing' the market and somehow beating other investors), while others may be considering financial products purely for cognitive reasons (such as a belief that they will generate higher returns in the long run and therefore the risk is worth them taking). There could also be a tension between the two - for example, objectively an RI can see the attraction of a risky investment but their sense of worry or fear - whether well founded or not - may prevent them from being willing to further consider it. Such interactions should be further investigated conceptually and empirically.

Finally, we limit our investigation to situations in which RIs encounter a new financial product from a provider whom they have not dealt with before. We do not, in this study, explore existing relationships that RIs may hold with financial advisors or institutions or the relevance of brand names on choice behaviour.

\section{CONCLUSIONS}

In summary, our study finds that variables related to product information as well as life variables influence RI intentions alongside the more established ATFR. Hence, the range of 
domain-specific and general impact factors that apply and interact in the context of RI decisionmaking warrants further investigation. This may inform future research and practice on how financial products are usefully marketed and how to engage with RIs cognitively and emotionally when selling financial products. 


\section{REFERENCES}

Adams, M. and W. Jiang (2017). 'Do chief executives' traits affect the financial performance of risk-trading firms? Evidence from the UK insurance industry', British Journal of Management, 28, pp. 481-501.

Ahammad, M. F., S. Y. Tarba, J. G. Frynas and A. Scola (2017). 'Integration of non-market and market activities in cross-border mergers and acquisitions', British Journal of Management, 28, pp. 629-648.

Ahlers, O., A. Hack, K. Madison, M. Wright and F. W. Kellermanns (2017). 'Is it all about money? Affective commitment and the difference between family and non-family sellers in buyouts', British Journal of Management, 28, pp. 159-179.

Arch, E. C. (1993). 'A motivational basis for sex-differences', Psychological Reports, 73, pp. $3-11$.

Arnett, J. (1994). 'Sensation seeking: A new conceptualization and a new scale', Personality and Individual Differences, 16, pp. 289-296.

Arnold, M. B. (1960). Emotion and personality. New York: Columbia University Press.

Ashkanasy, N. M., R. H. Humphrey and Q. N. Huy (2017). 'Integrating emotions and affect in theories of management', Academy of Management Review, 42, pp. 175-189.

Baker, M. J. and G. A. Churchill (1977). 'The impact of physically attractive models on advertising evaluations', Journal of Marketing Research, 14, pp. 538-555.

Bank of England (2018). News \& Events | Bank of England. [online] Bankofengland.co.uk. Available at: http://www.bankofengland.co.uk/statistics/Pages/mc/2017/jun.aspx [Accessed 19 Mar. 2018].

Barberis, N., M. Huang and R. H. Thaler (2006). 'Individual preferences, monetary gambles and stock market participation: A case for narrow framing', American Economic Review, 96, pp. 1069-1090.

Barroso, C. and A. Picón (2012). 'Multi-dimensional analysis of perceived switching costs', Industrial Marketing Management, 41, pp. 531-543.

Becker, J. M., K. Klein and M. Wetzels (2012). 'Hierarchical latent variable models in PLSSEM: Guidelines for using reflective-formative type models', Long Range Planning, 45, pp. 359-394.

Bluethgen R, S. Meyer and A. Hackethal (2008a). 'High-quality advice wanted', EBS Business School Working paper series. 
Bluethgen, R., A. Gintschel, A. Hackethal, and A. Mueller (2008b). 'Financial advice and individual investors' portfolios', EBS Business School Working paper series.

Boulding, W., A. Kalra, R. Staelin and V. A. Zeithaml (1993). 'A dynamic process model of service quality: From expectations to behavioural intentions', Journal of Marketing Research, 30, pp. 7-27.

Braun, T., A. I. Ferreira, T. Schmidt and J. Sydow (2018). 'Another post-heroic view on entrepreneurship: The role of employees in networking the start-up process', British Journal of Management, $\mathbf{0 0}$, pp. 1-18.

Brooks, C., I. Sangiorgi, C. Hillenbrand and K. Money (2017). 'Experience wears the trousers', Working Paper, Henley Business School, University of Reading, UK.

Brooks, C., I. Sangiorgi, C. Hillenbrand and K. Money (2018). 'Why are older investors less willing to take financial risks?', International Review of Financial Analysis, 56, pp. 52-72,

Brown, S. P., P. M. Homer and J. J. Inman (1998). 'A meta-analysis of relationships between ad-evoked feelings and advertising responses', Journal of Marketing Research, 35, pp. 114 126.

Browning, C. and M. Finke (2015). 'Cognitive ability and the stock reallocations of retirees during the great recession', Journal of Consumer Affairs, 49, pp. 356-375.

Chaiken, S. (1980). 'Heuristic versus systematic information processing and the use of source versus message cues in persuasion', Journal of Personality and Social Psychology, 39, pp.752766.

Cheah, E. T., D. Jamali, J. E. Johnson and M. C. Sung (2011). 'Drivers of corporate social responsibility attitudes: The demography of socially responsible investors', British Journal of Management, 22, pp. 305-323.

Chin, W. W. (1998). 'Commentary: Issues and opinion on structural equation modeling', MIS Quarterly, 22, pp. 7-16.

Chin, W. W. (2010). How to write up and report PLS analyses. In V. Vinzi, W. W. Chin, J. Henseler and H. Wang (eds) Handbook of partial least squares, pp. 655-690, Berlin: Springer.

Chou, K. L., T. Lee and A. H. Ho (2007). 'Does mood state change risk taking tendency in older adults?', Psychology and Aging, 22, pp. 310-318.

Cooper, M. L., M. R. Frone, M. Russell and P. Mudar (1995). 'Drinking to regulate positive and negative emotions: A motivational model of alcohol use', Journal of Personality and Social Psychology, 69, pp. 990-1005. 
Corter, J. E., and Y. J. Chen (2006). 'Do investment risk tolerance attitudes predict portfolio risk?', Journal of Business and Psychology, 20, pp. 369-381.

Cotte, J., R. A. Coulter and M. Moore (2005). 'Enhancing or disrupting guilt: The role of ad credibility and perceived manipulative intent', Journal of Business Research, 58, pp. 361-368.

Cox, D.S. and W. B. Locander (1987). 'Product novelty: Does it moderate the relationship between ad attitudes and brand attitudes?', Journal of Advertising, 16, pp. 39-44.

Craske, M.G. (2003). The origins of phobias and disorders: Why more women than men. Elsevier, Oxford, UK.

Croy, G., P. Gerrans and C. Speelman (2010). 'The role and relevance of domain knowledge, perceptions of planning importance, and risk tolerance in predicting savings intentions', Journal of Economic Psychology, 31, pp. 860-871.

Delgado-García, J. B., D. La Fuente-Sabaté, J. Manuel and D. Quevedo-Puente (2010). 'Too negative to take risks? The effect of the CEO's emotional traits on firm risk', British Journal of Management, 21, pp. 313-326.

Derbaix, C. M. (1995). 'The impact of affective reactions on attitudes toward the advertisement and the brand: A step toward ecological validity', Journal of Marketing Research, 32, pp. 470-479.

Doll, W. J., W. Xia and G. Torkzadeh (1994). 'A confirmatory factor analysis of the end-user computing satisfaction instrument', MIS Quarterly, 18, pp.453-461.

Dubé, L. and K. Menon (2000). 'Multiple roles of consumption emotions in post-purchase satisfaction with extended service transactions', International Journal of Service Industry Management, 11, pp. 287-304.

Edwards, J. R. (2001). 'Multidimensional constructs in organizational behaviour research: An integrative analytical framework', Organizational Research Methods, 4, pp. 144-192.

Ellsworth, P. C. and K. R. Scherer (2003). 'Appraisal processes in emotion'. In R. J. Davidson, K. R. Sherer and H. H. Goldsmith (eds), Handbook of Affective Sciences, pp. 572595, Oxford: Oxford University Press.

Epstein, S. (1994). 'Integration of the cognitive and the psychodynamic unconscious', American Psychologist, 49, pp. 709-724.

Ewe, S. Y., F. A. Gul, C. K. Lee and C. Y. Yang (2018). 'The Role of Regulatory Focus and Information in Investment Choice: Some Evidence Using Visual Cues to Frame Regulatory Focus', Journal of Behavioural Finance, 19, pp. 89-100.

Fagley, N. S. and P.M. Miller (1997). 'Framing effects and arenas of choice: Your money or your life?', Organizational Behaviour and Human Decision Processes, 71, pp. 355-373. 
Farrell, L., T. R. Fry and L. Risse (2016). 'The significance of financial self-efficacy in explaining women's personal finance behaviour', Journal of Economic Psychology, 54, pp. $85-99$.

FCA (2017). FCA reveals findings from its first Financial Lives Survey. [online] Available at: https://www.fca.org.uk/news/press-releases/fca-reveals-findings-from-first-financial-livessurvey [Accessed 2 Feb. 2018].

Fehr, H., T. Epper, A. Bruhin, and R. Schubert (2007). 'Risk and rationality: The effect of incidental mood on probability weighting', Working paper no. 0703. Zurich: Socioeconomic Institute, University of Zurich.

FINRA (2012). Investor Knowledge Quiz: A helpful guide to learning more about investing. [online]: http://www.finra.org/sites/default/files/InvestorDocument/p014495.pdf/ [Accessed 21 Nov. 2017].

Flanagin, A. J. and M. J. Metzger (2000). 'Perceptions of Internet information credibility', Journalism \& Mass Communication Quarterly, 77, pp. 515-540.

Forgas, J. P. (1995). 'Mood and judgment: The affect infusion model (AIM)', Psychological Bulletin, 117, pp. 39-66.

Fredrickson, B. L. (1998). 'What good are positive emotions?', Review of General Psychology, 2, pp. 300-319.

Friesen, G. and T. Sapp (2007). 'Mutual fund flows and investor returns: An empirical evaluation of fund investor timing ability', Journal of Banking and Finance, 31, pp. 27962816.

Fujita, F., E. Diener and E. Sandvik (1991). 'Gender differences in negative affect and wellbeing: The case for emotional intensity', Journal of Personality and Social Psychology, 61, pp. $427-434$.

Gambetti, E. and F. Giusberti (2012). 'The effect of anger and anxiety traits on investment decisions', Journal of Economic Psychology, 33, pp. 1059-1069.

Geisser, S. (1974). 'A predictive approach to the random effect model', Biometrika, 61, pp. 101-107.

Glenister, M. (2014a). 'Investors exposed to risk-profiling 'ticking time bomb' - Money Marketing'. [online] Money Marketing. Available at: https://www.moneymarketing.co.uk/investors-exposed-to-risk-profiling-ticking-time-bomb/ [Accessed 10 Feb. 2018].

Glenister, M. (2014b). 'FCA: We still have concerns about risk profiling'. [online] Money Marketing. Available at: https://www.moneymarketing.co.uk/fca-we-still-have-concernsabout-risk-profiling/ [Accessed 10 Feb. 2018]. 
Goldsmith, R. E., B. A. Lafferty and S. J. Newell (2000). 'The impact of corporate credibility and celebrity credibility on consumer reaction to advertisements and brands', Journal of Advertising, 29, pp. 43-54.

Grable, J. and M. J. Roszkowski (2008). 'The influence of mood on the willingness to take financial risks', Journal of Risk Research, 11, pp. 905-923.

Grable, J. E. (2000). 'Financial risk tolerance and additional factors that affect risk taking in everyday money matters', Journal of Business and Psychology, 14, pp. 625-630.

Grable, J. E. (2017). 'Financial risk tolerance: A psychometric review', Research Foundation Briefs, 4, pp. 1-20.

Grable, J. E. and S.-H. Joo (2004). 'Environmental and biophysical factors associated with financial risk tolerance', Journal of Financial Counseling and Planning, 15, pp. 73-82.

Grable, J., S. Britt and F. Webb (2008). 'Environmental and biopsychosocial profiling as a means for describing financial risk-taking behaviour', Journal of Financial Counseling and Planning, 19, pp. 3-18.

Griffiths, P. E. (2008). What emotions really are: The problem of psychological categories. London: University of Chicago Press.

Habib, M., M. Cassotti, S. Moutier, O. Houdé and G. Borst (2015). 'Fear and anger have opposite effects on risk seeking in the gain frame', Frontiers in Psychology, 6, pp. 1-7.

Hair J., M. Sarstedt, L. Hopkins and V. G. Kuppelwieser (2014). 'Partial least squares structural equation modeling (PLS-SEM): An emerging tool in business research', European Business Review, 26, pp. 106-121.

Hair Jr, J. F., M. Sarstedt, C. M. Ringle and S. P. Gudergan (2018). Advanced issues in partial least squares structural equation modeling. London: SAGE Publications.

Hair Jr., J. F., G. T. M. Hult, C. Ringle and M. Sarstedt (2016). A primer on partial least squares structural equation modeling (PLS-SEM). London: Sage Publications.

Hair, Jr, J. F., M. Sarstedt, T. M. Pieper and C. M. Ringle (2012). 'The use of partial least squares structural equation modeling in strategic management research: A review of past practices and recommendations for future applications', Long Range Planning, 45, pp. 320 340 .

Harman, H. H. (1976). Modern factor analysis. University of Chicago Press: Chicago.

Hauff, J. C., A. Carlander, A. Gamble, T. Gärling and M. Holmen (2016). 'Breaking the ice of low financial involvement: Does narrative information format from a trusted sender increase savings in mutual funds?', International Journal of Bank Marketing, 34, pp. 151170 . 
Hayhoe, C. R., Leach, L. J., Turner, P. R., Bruin, M. J. and Lawrence, F. C. (2000). 'Differences in spending habits and credit use of college students', Journal of Consumer Affairs, 34, pp.113-133.

Hegner-Kakar, A. K., N. F. Richter and C. M. Ringle (2018). 'The customer loyalty cascade and its impact on profitability in financial services'. In N. K. Avkiran and C. Ringle (eds), Partial least squares structural equation modeling: Recent advances in banking and finance, pp. 53-75. Springer, Cham.

Helm, S. (2007). 'The role of corporate reputation in determining investor satisfaction and loyalty', Corporate Reputation Review, 10, pp. 22-37.

Henle, C. A. and M. A. Gross (2014). 'What have I done to deserve this? Effects of employee personality and emotion on abusive supervision', Journal of Business Ethics, 122, pp. 461474.

Henseler, J. and M. Sarstedt (2013). 'Goodness-of-fit indices for partial least squares path modeling', Computational Statistics, 28, pp. 565-580.

Henseler, J. and W. W. Chin (2010). 'A comparison of approaches for the analysis of interaction effects between latent variables using partial least squares path modeling', Structural Equation Modeling, 17, pp. 82-109.

Hillenbrand, C., K. Money and A. Ghobadian (2013). 'Unpacking the mechanism by which corporate responsibility impacts stakeholder relationships', British Journal of Management, 24, pp. 127-146.

Hira, T. K. and O. M. Mugenda (1998). 'Predictors of financial satisfaction: Differences between retirees and non-retirees', Journal of Financial Counseling and Planning, 9, pp. 7584.

Hoffmann, A. O. and D. Ketteler (2015). 'How experiences with trading a company's stock influence customer attitudes and purchasing behaviour', International Journal of Bank Marketing, 33, pp. 963-992.

Holler, M., E. Hoelzl, E. Kirchler, S. Leder and L. Mannetti (2008). "Framing of information on the use of public finances, regulatory fit of recipients and tax compliance", Journal of Economic Psychology, 29, pp. 597-611.

Hunt, S., N. Stewart and R. Zaliauskas (2015). 'Two plus two makes five? Survey evidence that investors overvalue structured deposits', FCA Occasional Paper No. 9.

Hwang, J., Y. S. Yoon and N. H. Park (2011). 'Structural effects of cognitive and affective responses to web advertisements, website and brand attitudes, and purchase intentions: The case of casual-dining restaurants', International Journal of Hospitality Management, 30, pp. 897-907. 
Investinganswers.com. (2018). 'Retail Investor Definition \& Example | InvestingAnswers'. [online] Available at: http://www.investinganswers.com/financial-dictionary/investing/retailinvestor-911 [Accessed 1 Mar. 2018].

Irwin, C. E. and S. G. Millstein (1986). 'Biopsychosocial correlates of risk-taking behaviours during adolescence: Can the physician intervene?', Journal of Adolescent Health Care, 7, pp. $82-96$.

Izard C. E. (1977). Human emotions. New York: Plenum.

Izard, C. E. (2013). Patterns of emotions: A new analysis of anxiety and depression. London: Academic Press.

J.P. Morgan Investment Trust Team (2017). 'Brexit: EU \& UK reach divorce terms'. [online] Available at: https://am.jpmorgan.com/gb/en/asset-management/gim/adv/insights/marketbulletin-brexit-agreement-december-2017 [Accessed 19 Feb. 2018].

Jarvis, D., S. MacKenzie and P. Podsakoff (2003). 'A critical review of construct indicators and measurement model misspecification in marketing and consumer research', Journal of Consumer Research, 30, pp. 199-218.

Judge, T. A., C. J. Thoresen, V. Pucik and T. M. Welbourne (1999). 'Managerial coping with organizational change: A dispositional perspective', Journal of Applied Psychology, 84, p. $107-122$.

Kahneman, D. and A. Tversky (1979). 'Prospect theory: An analysis of decisions under risk', Econometrica, 47, pp. 263-291.

Kahneman, D. and A. Tversky (2013). 'Prospect theory: An analysis of decision under risk'. In L. Maclean and W. Ziemba (eds) Handbook of the fundamentals of financial decision making, Part I, pp. 99-127. Singapore: World Scientific Publishing.

Kim, E., S. Ratneshwar and E. Thorson (2017). 'Why narrative ads work: An integrated process explanation', Journal of Advertising, 46, pp. 283-296.

Kooij-de Bode, H. J., D. van Knippenberg and W. P. van Ginkel (2010). 'Good effects of bad feelings: Negative affectivity and group decision-making', British Journal of Management, 21, pp. 375-392.

Kozup, J. C., E. H. Creyer and S. Burton (2003). 'Making healthful food choices: The influence of health claims and nutrition information on consumers' evaluations of packaged food products and restaurant menu items', Journal of Marketing, 67, pp. 19-34.

Krueger, N. and P. R. Dickson (1994). 'How believing in ourselves increases risk taking: Perceived self-efficacy and opportunity recognition', Decision Sciences, 25, pp. 385-400. 
Kuppelwieser, V. G. and M. Sarstedt (2014). 'Applying the future time perspective scale to advertising research', International Journal of Advertising, 33, pp. 113-136.

Kuppens, P., I. van Mechelen, D. J. Smits and P. De Boeck (2003). 'The appraisal basis of anger: Specificity, necessity and sufficiency of components', Emotion, 3, pp. 254-269.

Lauriola, M., A. Panno, I. P. Levin and C. W. Lejuez (2014). 'Individual differences in risky decision making: A meta-analysis of sensation seeking and impulsivity with the balloon analogue risk task', Journal of Behavioural Decision Making, 27, pp. 20-36.

Law, K. S., C. Wong and W. H. Mobley (1998). 'Toward a taxonomy of multidimensional constructs', Academy of Management Review, 23, pp. 741-755.

Lerner, J. S. and D. Keltner (2000). 'Beyond valence: Toward a model of emotion-specific influences on judgement and choice’, Cognition \& Emotion, 14, pp. 473-493.

Lerner, J. S. and D. Keltner (2001). 'Fear, anger, and risk', Journal of Personality and Social Psychology, 81, pp. 146-159.

Lerner, J. S., R. M. Gonzalez, D. A. Small and B. Fischhoff (2003). 'Effects of fear and anger on perceived risks of terrorism: A national field experiment', Psychological Science, 14, pp. $144-150$.

Lerner, J. S., Y. Li, P. Valdesolo and K. S. Kassam (2015). 'Emotion and decision making', Annual Review of Psychology, 66, pp. 799-823.

Levin, A. M. and I. P. Levin (2010). 'Packaging of healthy and unhealthy food products for children and parents: the relative influence of licensed characters and brand names', Journal of Consumer Behaviour, 9, pp. 393-402.

Liljander, V. and T. Strandvik (1997). 'Emotions in service satisfaction', International Journal of Service Industry Management, 8, pp. 148-169.

Lindell, M. K. and D. J. Whitney (2001). 'Accounting for common method variance in crosssectional research designs', Journal of Applied Psychology, 86, pp. 114-121.

Loewenstein, G. and J. S. Lerner (2003). 'The role of affect in decision making'. In R.J. Davidson, K.R. Sherer and H.H. Goldsmith (eds), Handbook of affective sciences, pp. 619642, Oxford: Oxford University Press.

Loewenstein, G. F., E. U. Weber, C. K. Hsee and N. Welch (2001). 'Risk as feelings', Psychological Bulletin, 127, pp. 267-286.

Lohmöller, J. B. (1989). Latent Variable Path Modeling with Partial Least Squares. Heidelberg: Physica-Verlag. 
Loomes, G. and R. Sugden (1982). 'Regret theory: An alternative theory of rational choice under uncertainty', Economic Journal, 92, pp. 805-824.

Lowery, W. (2004). 'More control, but not clarity in non-linear web stories', Newspaper Research Journal, 25, pp. 83-97.

Lu, L. C., W. P. Chang and H. H. Chang (2014). 'Consumer attitudes toward blogger's sponsored recommendations and purchase intention: The effect of sponsorship type, product type, and brand awareness', Computers in Human Behaviour, 34, pp. 258-266.

Lucey, B. M. and M. Dowling (2005). 'The role of feelings in investor decision-making', Journal of Economic Surveys, 19, pp. 211-237.

MacCrimmon, K. R. and D. A. Wehrung (1984). 'The risk in-basket', Journal of Business, 57, pp. 367-387.

MacKenzie, S. B. and R. J. Lutz (1989). 'An empirical examination of the structural antecedents of attitude toward the ad in an advertising pretesting context', The Journal of Marketing, 53, pp. 48-65.

MacKenzie, S. B., P. M. Podsakoff and C. B. Jarvis (2005). 'The problem of measurement model misspecification in behavioural and organisational research and some recommended solutions', Journal of Applied Psychology, 90, pp. 710-730.

McCann, S. J. H., L. L. Stewin and R. H. Short (1991). 'Sex differences, social desirability, masculinity and the tendency to worry', Journal of Genetic Psychology, 152, pp. 295-301.

Mehta, A. and S. Purvis (1997). 'Evaluating advertising effectiveness through advertising response modeling (ARM)'. In W. D. Wells (ed) Measuring advertising effectiveness, pp. 325334. Mahwah, NJ: Lawrence Erlbaum Associates.

Mehta, A. and S. Purvis (2006). 'Reconsidering recall and emotion in advertising', Journal of Advertising Research, 46, pp. 49-56.

Metzger, M. J., A. J. Flanagin, K. Eyal, D. R. Lemus and R. M. McCann (2003). 'Credibility for the 21st century: Integrating perspectives on source, message, and media credibility in the contemporary media environment', Annals of the International Communication Association, 27, pp. 293-335.

Meyerowitz, B. E. and S. Chaiken (1987). 'The effect of message framing on breast selfexamination attitudes, intentions, and behaviour', Journal of Personality and Social Psychology, 52, pp. 500-510.

Michenaud, S. and B. Solnik (2008). 'Applying regret theory to investment choices: Currency hedging decisions', Journal of International Money and Finance, 27, pp. 677-694. 
Mishra, S. and D. Novakowski (2016). 'Personal relative deprivation and risk: An examination of individual differences in personality, attitudes, and behavioural outcomes', Personality and Individual Differences, 90, pp. 22-26.

Moneva, J. M. and E. Ortas (2010). 'Corporate environmental and financial performance: A multivariate approach', Industrial Management \& Data Systems, 110, pp. 193-210.

Montford, W. and R. E. Goldsmith (2016). 'How gender and financial self-efficacy influence investment risk taking', International Journal of Consumer Studies, 40, pp. 101-106.

Morris, J. D., C. Woo, J. A. Geason and J. Kim (2002). 'The power of affect: Predicting intention', Journal of Advertising Research, 42, pp. 7-17.

Nair, S. R., M. Demirbag, K. Mellahi and K. G. Pillai (2018). 'Do parent units benefit from reverse knowledge transfer?', British Journal of Management, 29, pp. 428-444.

Netemeyer, R. G., D. Warmath, D. Fernandes and Jr. J. G. Lynch (2017). 'How am I doing? Perceived financial well-being, its potential antecedents, and its relation to overall wellbeing', Journal of Consumer Research, 45, pp. 68-89.

Newell, B. R., D. A. Lagnado, and D. R. Shanks (2007). Straight choices: The psychology of decision making. New York: Psychology Press.

Nguyen, Y. and C. N. Noussair (2014). 'Risk aversion and emotions', Pacific Economic Review, 19, pp. 296-312.

Nitti, M. and E. Ciavolino (2014). 'A deflated indicators approach for estimating secondorder reflective models through PLS-PM: An empirical illustration', Journal of Applied Statistics, 41, pp. 2222-2239.

Nitzl, C. (2016). 'The use of partial least squares structural equation modelling (PLS-SEM) in management accounting research: Directions for future theory development', Journal of Accounting Literature, 37, pp. 19-35.

Pålsson, A. M. (1996). 'Does the degree of relative risk aversion vary with household characteristics?', Journal of Economic Ppsychology, 17, pp. 771-787.

Perry, V. G. and M. D. Morris (2005). 'Who is in control? The role of self-perception, knowledge, and income in explaining consumer financial behaviour', Journal of Consumer Affairs, 39, pp. 299-313.

Petty, R. E., J. T. Cacioppo and D. Schumann (1983). 'Central and peripheral routes to advertising effectiveness: The moderating role of involvement', Journal of Consumer Research, 10, pp. 135-146.

Pew Tan, H., D. Plowman and P. Hancock (2007). 'Intellectual capital and financial returns of companies', Journal of Intellectual Capital, 8, pp. 76-95. 
Phillips, D. M. and H. Baumgartner (2002). 'The role of consumption emotions in the satisfaction response', Journal of Consumer Psychology, 12, pp. 243-252.

Porter, N. M. and E. T. Garman (1993). 'Testing a conceptual model of financial well-being', Journal of Financial Counseling and Planning, 4, pp. 135-164.

Ramli, N. A., H. Latan and G. V. Nartea (2018). 'Why should PLS-SEM be used rather than regression? Evidence from the capital structure perspective'. In N. K. Avkiran and C. Ringle (eds), Partial least squares structural equation modeling: Recent advances in banking and finance, pp. 171-209. Springer, Cham.

Ricciardi, V. (2008). 'The financial psychology of worry and women', Working Paper, Kentucky State University.

Robb, C. A. and A. Woodyard (2011). 'Financial knowledge and best practice behaviour', Journal of Financial Counseling and Planning, 22, pp. 60-70.

Roberts, C. (2010). 'Correlations among variables in message and messenger credibility scales', American Behavioural Scientist, 54, pp. 43-56.

Rosenberg, M. (1965). Society and the adolescent self-image. Princeton, NJ: Princeton University Press.

Rusting, C. L. and R. J. Larsen (1995). 'Moods as sources of stimulation: Relationships between personality and desired mood states', Personality and Individual Differences, 18, pp. 321-329.

Rypma, B., V. Prabhakaran, J. E. Desmond and J. D. Gabrieli (2001). 'Age differences in prefrontal cortical activity in working memory', Psychology and Aging, 16, pp. 371-384.

Sahi, S. K. (2017). 'Psychological biases of individual investors and financial satisfaction', Journal of Consumer Behaviour, 16, pp. 511-535.

Sarstedt, M., C. M. Ringle, D. Smith, R. Reams and J. F. Hair Jr. (2014). 'Partial least squares structural equation modeling (PLS-SEM): A useful tool for family business researchers', Journal of Family Business Strategy, 5, pp. 105-115.

Sarstedt, M., J. Henseler and C. M. Ringle (2011). 'Multigroup analysis in partial least squares (PLS) path modeling: Alternative methods and empirical results', Advances in International Marketing, 22, pp. 195-218.

Schuitema, G. and J. I. Groot (2015). 'Green consumerism: The influence of product attributes and values on purchasing intentions', Journal of Consumer Behaviour, 14, pp. 57-69.

Schulreich, S., H. Gerhardt and H. R. Heekeren (2016). 'Incidental fear cues increase monetary loss aversion', Emotion, 16, pp. 402-412. 
Schunk, D. and C. Betsch (2006). 'Explaining heterogeneity in utility functions by individual differences in decision modes', Journal of Economic Psychology, 27, pp. 386-401.

Seetharaman, A., I. Niranjan, N. Patwa and A. Kejriwal (2017). 'A study of the factors affecting the choice of investment portfolio by individual investors in Singapore', Accounting and Finance Research, 6, pp. 153-168.

Sen, S., C. B. Bhattacharya and D. Korschun (2006). 'The role of corporate social responsibility in strengthening multiple stakeholder relationships: A field experiment', Journal of the Academy of Marketing Science, 34, pp. 158-166.

Simon, E. (2016). 'Is financial advice worth the fees?' [online] The Telegraph. Available at: https:/www.telegraph.co.uk/money/special-reports/is-financial-advice-worth-the-fees/ [Accessed 11 Feb. 2018].

Sivaramakrishnan, S., M. Srivastava and A. Rastogi (2017). 'Attitudinal factors, financial literacy, and stock market participation', International Journal of Bank Marketing, 35, pp. 818-841.

Sizer, L. (2000). 'Towards a computational theory of mood', British Journal of Philosophical Science, 51, pp. 743-769.

Slovic, P., M. L. Finucane, E. Peters, and D. G. MacGregor (2004). 'Risk as analysis and risk as feelings: Some thoughts about affect, reason, risk, and rationality', Risk Analysis, 24, pp. $311-322$.

Smith, C. A. and P. C. Ellsworth (1985). 'Patterns of cognitive appraisal in emotions', Journal of Personality and Social Psychology, 48, pp. 813-838.

Staddon, J. (2017) Scientific Method: How science works, fails to work or pretends to work. Abingdon: Taylor and Francis.

Stone, M. (1974). 'Cross-validatory choice and assessment of statistical predictions', Journal of the Royal Statistical Society, 36, pp. 111-147.

Sung, J. and S. Hanna (1996). 'Factors related to risk tolerance', Journal of Financial Counseling and Planning, 7, pp. 11-19.

Tang, N. and A. Baker (2016). 'Self-esteem, financial knowledge and financial behaviour', Journal of Economic Psychology, 54, pp. 164-176.

Tronvoll, B. (2011). 'Negative emotions and their effect on customer complaint behaviour', Journal of Service Management, 22, pp. 111-134.

Voorhees, C. M., M. K. Brady and D. M. Horowitz (2006). 'A voice from the silent masses: An exploratory and comparative analysis of noncomplainers', Journal of the Academy of Marketing Science, 34, pp. 514-527. 
Wang, H., J. Zhang, L. Wang and S. Liu (2014). 'Emotion and investment returns: Situation and personality as moderators in a stock market', Social Behaviour and Personality, 42, pp. $561-569$.

Wang, X. T. (2006). 'Emotions within reason: Resolving conflicts in risk preference', Cognition and Emotion, 20, pp. 1132-52.

Watson, D. and A. Tellegen (1985). 'Toward a consensual structure of mood', Psychological Bulletin, 98, pp. 219-235.

Watson, D., and L. A. Clark (1994). The PANAS-X: Manual for the positive affect and negative affect schedule-expanded form. Cedar Rapids: University of Iowa.

Watson, D., D. Wiese, J. Vaidya and A. Tellegen (1999). 'The two general activation systems of affect: Structural findings, evolutionary considerations, and psychobiological evidence', Journal of Personality and Social Psychology, 76, pp. 820-838.

Watson, D., L. A. Clark and A. Tellegen (1988). 'Development and validation of brief measures of positive and negative affect: The PANAS scales', Journal of Personality and Social Psychology, 54, pp. 1063-1070.

Weber, E. U. and R. A. Milliman (1997). 'Perceived risk attitudes: Relating risk perception to risky choice', Management Science, 43, pp.123-144.

Weber, E. U., A.-R. Blais and E. Betz (2002). 'A Domain-specific risk-attitude scale: Measuring risk perceptions and risk behaviours', Journal of Behavioural Decision Making, 15, pp. 263-290.

West, B., C. Hillenbrand, K. Money, A. Ghobadian and R. D. Ireland (2016). 'Exploring the impact of social axioms on firm reputation: A stakeholder perspective', British Journal of Management, 27, pp. 249-270.

Wetzels, M., G. Odekerken-Schröder and C. van Oppen (2009). 'Using PLS path modeling for assessing hierarchical construct models: Guidelines and empirical illustration', MIS Quarterly, 33, pp.177-195.

Williams, S. (2004). 'The impact of mood on managerial perceptions', Research and Practice in Human Resource Management, 12, pp. 128-139.

Wong, A. and B. Carducci (2016). 'Do sensation seeking, control orientation, ambiguity, and dishonesty traits affect financial risk tolerance?', Managerial Finance, 42, pp. 34-41.

Wong, A. and B. J. Carducci (1991). 'Sensation seeking and financial risk taking in everyday money matters', Journal of Business and Psychology, 5, pp. 525-530.

Wright, M., N. Wilson, J. Gilligan, N. Bacon and K. Amess (2016). 'Brexit, private equity and management', British Journal of Management, 27, pp. 682-686. 
Wright, W. F., and G. H. Bower (1992). 'Mood effects on subjective probability assessment', Organisational Behaviour and Human Decision Processes, 52, pp. 276-291.

Yao, R., S. D. Hanna and S. Lindamood (2004). 'Changes in financial risk tolerance, 19832001', Financial Services Review, 13, pp. 249-266.

Yuen, K. S. and T. M. Lee (2003). 'Could mood state affect risk-taking decisions?', Journal of Affective Disorders, 75, pp. 11-18.

Zhou, R. and M. T. Pham (2004). 'Promotion and prevention across mental accounts: When financial products dictate consumers' investment goals', Journal of Consumer Research, 31, pp.125-135.

Zuckerman, M. (1979). Sensation Seeking, Hillsdale, NJ: Lawrence Erlbaum Association. 
Footnotes 
${ }^{1}$ A retail investor is an individual who purchases securities for his or her own personal account rather than for an organisation (Investinganswers.com, 2018).

${ }^{2}$ We employ the term 'engage with financial products' as a summary expression for a respondent's interest in following up on the information contained in the leaflet that they were shown. We use a slightly broad term to cover all possible levels of interest including a potential willingness to invest in the portfolio, a desire to obtain more information before making a decision, an interest in speaking to a financial adviser about the product, and so on.

${ }^{3}$ We employ the term 'life variables' as a summary expression for general impact factors relating to personality factors and/or life circumstances of RIs. This builds on previous literature by authors such as Grable and Joo (2004), Grable et al. (2008), Adams and Jian (2017) who use varying terms to express person-related factors.

${ }^{4}$ General demographics (such as age, gender, income, financial knowledge and experience, house ownership) were mostly situated at the end of the survey, unless they were needed at the beginning for screening purposes. Grable and Joo's (2004) measure of net-worth was adapted with a question 'Suppose you are to sell all of your major possessions (including your home), turn all of your investments and other assets into cash, and pay all of your debts. Would you be in debt, break even, or have something left over?' Financial knowledge was measured by adapting FINRA's (2012) real knowledge quiz task. The quiz was then re-coded as a rank order measure on a 5-point Likert scale, where a score of 1 indicates poor knowledge and a score of 5 indicates excellent knowledge in the area of finance.

${ }^{5}$ A type II model is able to accommodate LOCs, measured reflectively and HOCs, measured formatively. LOCs in our study do not share a common cause but form a thematic concept that can be seen to mediate the relationship between LOCs and the outcome variable (Barroso and Picón, 2012; Becker, Klein and Wetzels, 2012). Removing one LOC will not lead to differences in theoretical underpinning of the HOC (Nitti and Ciavolino, 2014).

${ }^{6}$ Since respondents were recruited by Qualtrics, the company ensured full completion of the survey.

${ }^{7}$ A straight-liner is typically defined as a response pattern 'when a respondent marks the same response for a high proportion of the questions' (Hair et al., 2016: p. 72).

${ }^{8}$ In addition, the sample screening included ethnicity as a critical demographic variable. However, the analysis revealed that $88.5 \%$ of the sample fell into the category "White British", while other ethnic groups comprised $11.5 \%$ of responses. Such an unequal spread of data across ethnic groups does not allow testing for specific sub-group differences. 
${ }^{9}$ PLS-SEM is considered appropriate in dealing with non-parametric estimations within complex structural models (Hair et al., 2012; Henseler and Chin, 2010; Sarstedt et al., 2014). For this study PLS-SEM was operationalised within the software SmartPLS 3.2.7 (Hair et al., 2016, 2018).

${ }^{10}$ Reliability assessment includes the analysis of composite reliability, indicator reliability, convergent validity (i.e., average variance extracted) and discriminant validity (i.e., the Fornell-Larcker criterion and cross loadings). A small number of outer loadings of the independent constructs (relating to evaluations and credibility of the leaflet, self-esteem and sensation seeking) were found to be very slightly above the suggested thresholds for indicator reliability. After conducting the test of relevance for outer loadings (through AVE comparisons), 11 items in total were removed from the model.

${ }^{11}$ It remains unclear from the results in this study, however, whether the relationship between ATFR and readiness to engage with financial products will indeed serve the individual client. The findings are merely indicative of a strong association while the directionality of this relationship (i.e., are investors who engage more in financial products more risk tolerant as a consequence or is risk tolerance leading to higher engagement), or indeed the foundation for risk tolerance (i.e., representing more capacity for risk or merely more appetite for risk), and hence the severity of potential consequences should investments fail to deliver the desired results, remain unclear in the context of RI ATFR.

${ }^{12}$ RIs with more experience and knowledge and also with more assets at their disposal are likely to feel positive about the product and are also more likely to engage if they feel more positive towards finance/investment generally, whereas the impact of negative emotions towards these variables is more heavily expressed by participants who may not have the same financial options and less experience and knowledge as well.

${ }^{13}$ For example, the Bank of England Money and Credit Statistics team are looking for ways to improve the capability and understanding of individual decision-making processes (Bank of England, 2018). 


\section{Figure 1. Conceptual Framework}

\begin{tabular}{|c|c|c|}
\hline $\begin{array}{c}\text { Product } \\
\text { Information }\end{array}$ & $\begin{array}{l}\text { H1a Evaluation of product information (+) } \\
\text { H1b Credibility of product information (+) } \\
\text { H1c Positive emotions towards product information (+) } \\
\text { H1d Negative emotions towards product information (-) }\end{array}$ & \\
\hline $\begin{array}{c}\text { Attitude } \\
\text { towards } \\
\text { finance }\end{array}$ & $\begin{array}{l}\text { H2a Attitude towards financial risk (ATFR) (+) } \\
\text { H2b Financial satisfaction (+) } \\
\text { H2c Positive emotions towards finance (+) } \\
\text { H2d Negative emotions towards finance (-) }\end{array}$ & $\begin{array}{l}\text { RI intention to engage with } \\
\text { financial products } \\
\text { (e.g. Interest to invest in the } \\
\text { offered portfolio; interested } \\
\text { to book a session with an } \\
\text { advisor; recommending this } \\
\text { portfolio to friends/family) }\end{array}$ \\
\hline $\begin{array}{c}\text { Life } \\
\text { variables }\end{array}$ & $\begin{array}{l}\text { H3a Self-esteem (+) } \\
\text { H3b Sensation seeking (+) } \\
\text { H3c Positive emotions towards life }(+) \\
\text { H3d Negative emotions towards life }(-)\end{array}$ & \\
\hline
\end{tabular}


Table 1. First- and second-order constructs

\begin{tabular}{|l|c|c|c|}
\hline First order constructs & $\begin{array}{c}\text { Product } \\
\text { Information }\end{array}$ & $\begin{array}{c}\text { Attitude towards } \\
\text { finance }\end{array}$ & Life variables \\
\hline Evaluation of product information & $\mathrm{x}$ & & \\
\hline Credibility of product information & $\mathrm{x}$ & & \\
\hline Positive emotions towards product information & $\mathrm{x}$ & & \\
\hline Negative emotions towards product information & $\mathrm{x}$ & $\mathrm{x}$ & \\
\hline Attitude towards financial risk (ATFR) & & $\mathrm{x}$ & \\
\hline Financial satisfaction & & $\mathrm{x}$ & $\mathrm{x}$ \\
\hline Positive emotions towards finance & & & $\mathrm{x}$ \\
\hline Negative emotions towards finance & & & $\mathrm{x}$ \\
\hline Self-esteem & & & $\mathrm{x}$ \\
\hline Sensation seeking & & & \\
\hline Positive emotions towards life & & & \\
\hline Negative emotions towards life & & & \\
\hline
\end{tabular}


Table 2: Sample demographics

\begin{tabular}{|l|l|c|c|}
\hline \multicolumn{2}{|c|}{ Demographics } & N & Percent \\
\hline \multirow{2}{*}{ Gender } & Female & 486 & $50.1 \%$ \\
\cline { 2 - 4 } & Male & 484 & $49.9 \%$ \\
\hline \multirow{2}{*}{ Age } & Age $(18-39$ y.o $)$ & 242 & $24.9 \%$ \\
\cline { 2 - 4 } & Age $(40+$ y.o. $)$ & 728 & $75.1 \%$ \\
\hline \multirow{2}{*}{ Income } & Income (<£50k) & 633 & $65.3 \%$ \\
\cline { 2 - 4 } & Income (>£50k) & 337 & $34.7 \%$ \\
\hline \multirow{2}{*}{ Experience } & Experienced & 559 & $57.6 \%$ \\
\cline { 2 - 4 } & Not experienced & 411 & $42.4 \%$ \\
\hline \multirow{2}{*}{ Own property } & Own property & 762 & $78.6 \%$ \\
\cline { 2 - 4 } & Not own property & 208 & $21.4 \%$ \\
\hline \multirow{2}{*}{ Net-worth } & High net-worth & 748 & $77.1 \%$ \\
\cline { 2 - 4 } & Low net-worth & 222 & $22.9 \%$ \\
\hline \multirow{2}{*}{ Knowledge } & High knowledge & 410 & $42.3 \%$ \\
\cline { 2 - 4 } & Low knowledge & 560 & $57.7 \%$ \\
\hline TOTAL SAMPLE & & & 970 \\
\hline
\end{tabular}


Table 3. Test of hypotheses

\begin{tabular}{|l|c|c|c|c|c|}
\hline \multicolumn{1}{|c|}{ Model paths } & $\begin{array}{c}\text { Path } \\
\text { coefficients }\end{array}$ & $\boldsymbol{t}$-value & $\boldsymbol{p}$-value & Hypothesis & Support \\
\hline $\begin{array}{l}\text { Evaluation of product information } \rightarrow \text { RIs } \\
\text { intentions }\end{array}$ & $\mathbf{0 . 2 5 2}$ & $\mathbf{7 . 4 6}$ & $\mathbf{0}$ & Hypothesis 1a & supported \\
\hline $\begin{array}{l}\text { Credibility of product information } \rightarrow \text { RIs } \\
\text { intentions }\end{array}$ & $\mathbf{0 . 0 8 9}$ & $\mathbf{2 . 8 6 6}$ & $\mathbf{0 . 0 0 4}$ & Hypothesis 1b & supported \\
\hline $\begin{array}{l}\text { Positive emotions towards product } \\
\text { information } \rightarrow \text { RIs intentions }\end{array}$ & $\mathbf{0 . 3 7 8}$ & $\mathbf{9 . 8 1 6}$ & $\mathbf{0}$ & Hypothesis 1c & supported \\
\hline $\begin{array}{l}\text { Negative emotions towards product } \\
\text { information } \rightarrow \text { RIs intentions }\end{array}$ & $\mathbf{- 0 . 0 7 9}$ & $\mathbf{3 . 0 0 5}$ & $\mathbf{0 . 0 0 3}$ & Hypothesis 1d & supported \\
\hline $\begin{array}{l}\text { Attitude towards financial risk } \rightarrow \text { RIs } \\
\text { intentions }\end{array}$ & $\mathbf{0 . 2 3 4}$ & $\mathbf{8 . 6 0 9}$ & $\mathbf{0}$ & Hypothesis 2a & supported \\
\hline Financial Satisfaction $\rightarrow$ RIs intentions & 0.005 & 0.185 & 0.854 & Hypothesis 2a & not supported \\
\hline $\begin{array}{l}\text { Positive emotions towards finance } \rightarrow \text { RIs } \\
\text { intentions }\end{array}$ & -0.055 & 1.323 & 0.186 & Hypothesis 2c & not supported \\
\hline $\begin{array}{l}\text { Negative emotions towards finance } \rightarrow \text { RIs } \\
\text { intentions }\end{array}$ & 0.003 & 0.096 & 0.923 & Hypothesis 2d & not supported \\
\hline Self-esteem $\rightarrow$ RIs intentions & 0.006 & 0.171 & 0.864 & Hypothesis 3a & not supported \\
\hline Sensation seeking $\rightarrow$ RIs intentions & $\mathbf{0 . 0 8 3}$ & $\mathbf{3 . 2 2 7}$ & $\mathbf{0 . 0 0 1}$ & Hypothesis 3b & supported \\
\hline $\begin{array}{l}\text { Positive emotions towards life } \rightarrow \text { RIs } \\
\text { intentions }\end{array}$ & -0.048 & 1.341 & 0.18 & Hypothesis 3c & not supported \\
\hline $\begin{array}{l}\text { Negative emotions towards life } \rightarrow \text { RIs } \\
\text { intentions }\end{array}$ & $\mathbf{0 . 0 9 7}$ & $\mathbf{3 . 0 7 4}$ & $\mathbf{0 . 0 0 2}$ & Hypothesis 3d & supported \\
\hline
\end{tabular}


Table 4. Results for control variables

\begin{tabular}{|c|c|}
\hline Control Variable & Significant results \\
\hline Gender & $\begin{array}{l}\text { The path between positive emotions towards product information and intentions } \\
(\mathrm{H} 1 \mathrm{c}) \text { is significantly stronger for male participants }\left(\beta_{\text {male }}=0.444, \beta_{\text {female }}=0.288 \text {, }\right. \\
p<0.01) \text {, while the path from negative emotions towards product information and } \\
\text { intention }(\mathrm{H} 1 \mathrm{~d}) \text { is significantly stronger for female participants }\left(\beta_{\text {female }}=-0.153 \text {, }\right. \\
\left.\beta_{\text {male }}=-0.005, p<0.01\right) \text {. Also, the path from positive emotions towards finance to } \\
\text { intentions }(\mathrm{H} 2 \mathrm{c}) \text { is significantly stronger for male participants }\left(\beta_{\text {male }}=-0.111 \text {, }\right. \\
\left.\beta_{\text {female }}=0.008, p<0.1\right)\end{array}$ \\
\hline Age & $\begin{array}{l}\text { To control for age, we categorize participants into age group }(1) \text { between } 18 \text { and } \\
39 \text { years and group }(2) \text { of } 40 \text { and above. } \\
\text { The path between negative emotions towards product information and intentions } \\
\text { (H1c) is stronger for older participants }\left(\beta_{\mathrm{Age} 2}=-0.104 ; \beta_{\mathrm{Agel}}=0.014, p<0.05\right) \text {. The } \\
\text { path between negative emotions towards finance and intentions }(\mathrm{H} 2 \mathrm{~d}) \text { is } \\
\text { significantly stronger for younger participants }\left(\beta_{\mathrm{Agel}}=-0.224 ; \beta_{\mathrm{Age} 2}=-0.026, p\right. \\
0.05) \text {. The path between positive emotions towards life and intentions }(\mathrm{H} 3 \mathrm{c}) \text { is } \\
\text { significantly stronger for older participants }\left(\beta_{\mathrm{Age} 2}=-0.073 ; \beta_{\mathrm{Agel}}=0.085, p<0.05\right) \text {, } \\
\text { while the link between self-esteem and intentions }(\mathrm{H} 3 \mathrm{a}) \text { is significantly stronger } \\
\text { for younger participants }\left(\beta_{\mathrm{Agel}}=0.127 ; \beta_{\mathrm{Age} 2}=0.043, p<0.05\right) \text {. }\end{array}$ \\
\hline Income & $\begin{array}{l}\text { To control for income, we categorize participants into income group }(1) \text { with an } \\
\text { income up to } 550 \mathrm{k} \text { and income group }(2) \text { with an income above } £ 50 \mathrm{k} \text {. } \\
\text { The path between credibility of product information }(\mathrm{H} 1 \mathrm{~b}) \text { and intentions is } \\
\text { stronger for income group }(2)\left(\beta_{<550 \mathrm{k}}=0.153, \beta_{\succ 550 \mathrm{k}}=0.059, p<0.1\right) \text {, as is the path } \\
\text { between negative emotions towards finance and intentions }(\mathrm{H} 2 \mathrm{~d}) \text { and intentions } \\
\left(\beta_{\succ 550 \mathrm{k}}=0.126 ; \beta_{<55 \mathrm{k}}=-0.043, p<0.01\right) \text {. }\end{array}$ \\
\hline Net-worth & $\begin{array}{l}\text { To control for net-worth, the sample is split into low (group 1) and high (group } 2) \\
\text { net-worth sub-samples using a central split. } \\
\text { Positive emotions towards product information }(\mathrm{H} 1 \mathrm{c}) \text { are found to have a } \\
\text { stronger impact on intentions for group } 2 \text { net-worth individuals }\left(\beta_{\text {high }}=0.408 \text {, }\right. \\
\left.\beta_{\text {low }}=0.23, p<0.05\right) \text {, as are positive emotions towards finance }(\mathrm{H} 2 \mathrm{c})\left(\beta_{\text {high }}=-0.102 \text {, }\right. \\
\left.\beta_{\text {low }}=0.097, p<0.05\right) \text {. }\end{array}$ \\
\hline Home ownership & $\begin{array}{l}\text { In terms of home ownership, the results suggest that negative emotions towards } \\
\text { finance }(\mathrm{H} 2 \mathrm{~d}) \text { impact intentions more amongst non-home-owners }\left(\beta_{\text {not own }}=-0.14 \text {, }\right. \\
\left.\beta_{\text {own }}=0.042 p<0.01\right) \text {. }\end{array}$ \\
\hline Investment experience & 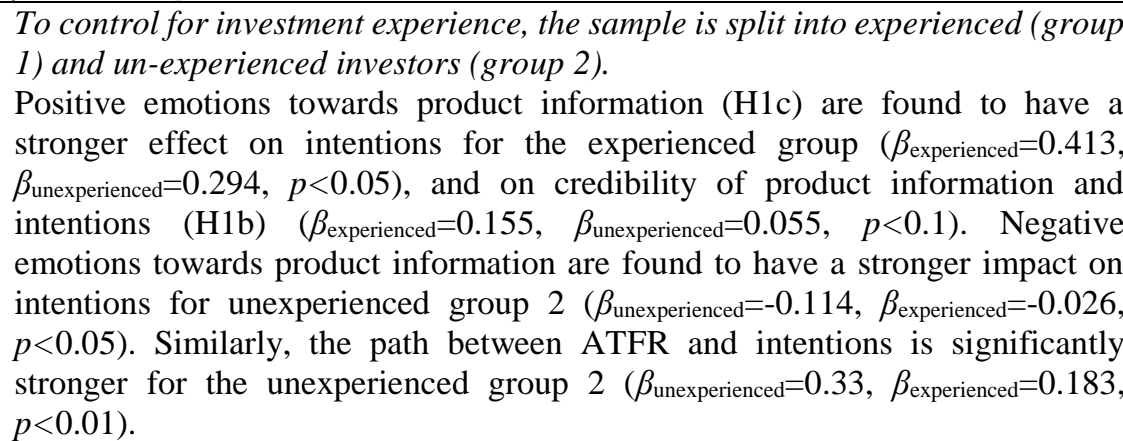 \\
\hline Financial Knowledge & $\begin{array}{l}\text { To control for the impact of financial knowledge, the sample is split into } \\
\text { knowledge group (1) who demonstrated low levels of financial knowledge and } \\
\text { group (2) with high knowledge participants. } \\
\text { The path between positive emotions towards product information and intentions } \\
\text { (H1c) is significantly stronger for knowledge group } 2\left(\beta_{\text {high }}=0.447, \beta_{\text {low }}=0.308 \text {, }\right. \\
p<0.05) \text {, while the impact of negative emotions towards product information } \\
\text { (H1d) is stronger for group } 1\left(\beta_{\text {low }}=-0.127, \beta_{\text {high }}=0.010, p<0.05\right) \text {. Finally, positive } \\
\text { emotions towards finance }(\mathrm{H} 2 \mathrm{c}) \text { impact more strongly on group } 2 \text { intentions } \\
\left(\beta_{\text {high }}=-0.180, \beta_{\text {low }}=0.021, p<0.01\right) \text {. }\end{array}$ \\
\hline
\end{tabular}


Table 5. Hierarchical component modelling

\begin{tabular}{|c|c|c|c|c|c|}
\hline & First- and second-order constructs & $\begin{array}{l}\text { Attitudes } \\
\text { towards } \\
\text { Finance }\end{array}$ & $\begin{array}{c}\text { Product } \\
\text { Information }\end{array}$ & $\begin{array}{c}\text { Life } \\
\text { Variables }\end{array}$ & $\begin{array}{c}\text { RIs } \\
\text { Intentions } \\
R^{2}=0.519\end{array}$ \\
\hline \multirow{12}{*}{ 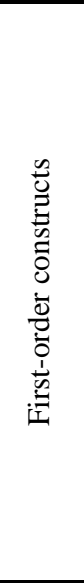 } & Evaluation of product information & \multirow{12}{*}{$\begin{array}{c}0.417 * * * \\
0.201 * * * \\
0.420 * * * \\
-0.297 * * *\end{array}$} & \multirow{12}{*}{$\begin{array}{c}0.384 * * * \\
0.331 * * * \\
0.414 * * * \\
-0.155 n . s .\end{array}$} & \multirow{12}{*}{$\begin{array}{l}0.383 * * * \\
0.341 * * * \\
0.372 * * * \\
-0.214 * * *\end{array}$} & \\
\hline & Credibility of product information & & & & \\
\hline & Positive emotions towards product information & & & & \\
\hline & Negative emotions towards product information & & & & \\
\hline & Attitude towards financial risk & & & & \\
\hline & Financial Satisfaction & & & & \\
\hline & Positive emotions towards finance & & & & \\
\hline & Negative emotions towards finance & & & & \\
\hline & Self-esteem & & & & \\
\hline & Sensation seeking & & & & \\
\hline & Positive emotions towards life & & & & \\
\hline & Negative emotions towards life & & & & \\
\hline \multirow{3}{*}{ 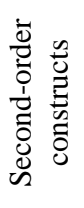 } & Attitudes towards Finance & $\mathrm{VIF}=1.675$ & \multirow{3}{*}{$\mathrm{VIF}=1.37$} & & $0.219 * * *$ \\
\hline & Product Information & & & & $0.616 * * *$ \\
\hline & Life Variables & & & $\mathrm{VIF}=1.401$ & $-0.081 * * *$ \\
\hline
\end{tabular}

$* * *$ indicates significance at the 0.01 level. 
Appendix 1. Example of the leaflet 
Appendix 2. Measurement model assessment

\begin{tabular}{|c|c|c|c|c|c|c|c|c|c|c|c|c|c|c|c|c|c|c|}
\hline Constructs & Mean & S.D. & $\begin{array}{c}\text { Cronbach's } \\
\text { Alpha }\end{array}$ & $\begin{array}{l}\text { Composite } \\
\text { Reliability }\end{array}$ & AVE & $\begin{array}{l}\text { Evaluation } \\
\text { of product } \\
\text { information }\end{array}$ & $\begin{array}{c}\text { Credibility } \\
\text { of product } \\
\text { information }\end{array}$ & \begin{tabular}{|c|} 
Positive \\
emotions \\
towards product \\
information \\
\end{tabular} & \begin{tabular}{|c|} 
Negative \\
emotions \\
towards product \\
information \\
\end{tabular} & \begin{tabular}{|c|}
$\begin{array}{c}\text { Attitude } \\
\text { towards } \\
\text { financial } \\
\text { risk }\end{array}$ \\
\end{tabular} & $\begin{array}{c}\text { Financial } \\
\text { Satisfaction }\end{array}$ & \begin{tabular}{|c|} 
Positive \\
emotions \\
towards \\
finance \\
\end{tabular} & \begin{tabular}{|c|} 
Negative \\
emotions \\
towards \\
finance \\
\end{tabular} & $\begin{array}{c}\text { Self- } \\
\text { esteem }\end{array}$ & $\begin{array}{c}\text { Sensation } \\
\text { seeking }\end{array}$ & \begin{tabular}{|c|}
$\begin{array}{c}\text { Positive } \\
\text { emotions } \\
\text { towards } \\
\text { life }\end{array}$ \\
\end{tabular} & $\begin{array}{c}\text { Negative } \\
\text { emotions } \\
\text { towards } \\
\text { life }\end{array}$ & Intent \\
\hline Evaluation of product information & 3.300 & 0.845 & 0.914 & 0.93 & 0.626 & 0.791 & & & & & & & & & & & & \\
\hline Credibility of product information & 3.339 & 0.740 & 0.824 & 0.877 & 0.589 & 0.672 & 0.767 & & & & & & & & & & & \\
\hline $\begin{array}{l}\text { Positive emotions towards } \\
\text { product information }\end{array}$ & 2.314 & 1.054 & 0.938 & 0.956 & 0.843 & 0.585 & 0.498 & 0.918 & & & & & & & & & & \\
\hline $\begin{array}{l}\text { Negative emotions towards } \\
\text { product information }\end{array}$ & 1.891 & 0.908 & 0.72 & 0.873 & 0.776 & -0.197 & -0.277 & 0.008 & 0.881 & & & & & & & & & \\
\hline Attitude towards financial risk & 2.673 & 0.805 & 0.904 & 0.918 & 0.556 & 0.276 & 0.277 & 0.369 & -0.348 & 0.745 & & & & & & & & \\
\hline Financial Satisfaction & 3.489 & 1.032 & 1 & 1 & 1 & 0.128 & 0.157 & 0.108 & -0.127 & 0.196 & 1 & & & & & & & \\
\hline $\begin{array}{l}\text { Positive emotions towards } \\
\text { finance }\end{array}$ & 2.737 & 1.024 & 0.91 & 0.937 & 0.787 & 0.375 & 0.357 & 0.684 & -0.15 & 0.6 & 0.214 & 0.887 & & & & & & \\
\hline $\begin{array}{l}\text { Negative emotions towards } \\
\text { finance }\end{array}$ & 2.528 & 1.087 & 0.797 & 0.906 & 0.828 & -0.164 & -0.156 & -0.091 & 0.521 & -0.494 & -0.324 & -0.302 & 0.91 & & & & & \\
\hline Self-esteem & 3.778 & 0.709 & 0.862 & 0.895 & 0.588 & 0.201 & 0.223 & 0.227 & -0.166 & 0.246 & 0.385 & 0.347 & -0.328 & 0.767 & & & & \\
\hline Sensation seeking & 3.137 & 0.905 & 0.507 & 0.75 & 0.501 & 0.193 & 0.245 & 0.331 & -0.181 & 0.393 & 0.117 & 0.406 & -0.223 & 0.379 & 0.708 & & & \\
\hline Positive emotions towards life & 3.340 & 0.743 & 0.912 & 0.926 & 0.559 & 0.253 & 0.287 & 0.42 & -0.117 & 0.265 & 0.316 & 0.537 & -0.21 & 0.644 & 0.411 & 0.748 & & \\
\hline Negative emotions towards life & 1.672 & 0.644 & 0.892 & 0.904 & 0.511 & -0.037 & -0.048 & 0.13 & 0.243 & -0.033 & -0.27 & 0.052 & 0.36 & -0.415 & -0.081 & -0.119 & 0.715 & \\
\hline Intent & 2.860 & 0.981 & 0.922 & 0.939 & 0.72 & 0.593 & 0.517 & 0.639 & -0.209 & 0.48 & 0.106 & 0.497 & -0.204 & 0.175 & 0.337 & 0.269 & 0.1 & 0.848 \\
\hline
\end{tabular}


Appendix 3. Demographic control variables

\begin{tabular}{|c|c|c|c|c|c|c|c|c|c|c|c|c|c|c|c|}
\hline \multirow{2}{*}{ Path Relationships } & \multicolumn{3}{|c|}{ GENDER } & \multicolumn{3}{|c|}{ AGE } & \multicolumn{3}{|c|}{ INCOME } & \multicolumn{3}{|c|}{ NET-WORTH } & \multicolumn{3}{|c|}{ OWN A HOUSE } \\
\hline & Female & Male & $p$-value & $\begin{array}{c}\text { Age 1 } \\
(18-39)\end{array}$ & $\begin{array}{l}\text { Age } 2 \\
(40+)\end{array}$ & $p$-value & $<£ 50 k$ & $>£ 50 k$ & $p$-value & High & Low & $p$-value & Own & Not own & $p$-value \\
\hline $\begin{array}{l}\text { Evaluation of product information -> } \\
\text { RIs intentions }\end{array}$ & $0.246 * * *$ & $0.252 * * *$ & 0.529 & $0.296 * * *$ & $0.24 * * *$ & 0.234 & $0.241^{* * *}$ & $0.315^{* * * *}$ & 0.841 & $0.233 * * *$ & $0.306 * * *$ & 0.838 & $0.316^{* * * *}$ & $0.23^{* * *}$ & 0.156 \\
\hline $\begin{array}{l}\text { Credibility of product information -> } \\
\text { RIs intentions }\end{array}$ & 0.056 & $0.118^{* *}$ & 0.828 & 0.041 & $0.103 * * *$ & 0.789 & 0.059 & $0.153 * * *$ & 0.919 & $0.103 * * *$ & 0.024 & 0.108 & 0.085 & $0.099 * * *$ & 0.566 \\
\hline $\begin{array}{l}\text { Positive emotions towards product } \\
\text { information -> RIs intentions }\end{array}$ & $0.288 * * *$ & $0.444^{* * * *}$ & 0.981 & $0.434 * * *$ & $0.355^{* * *}$ & 0.193 & $0.372^{* * * *}$ & $0.321^{* * * *}$ & 0.268 & $0.408^{* * * *}$ & $0.23^{* * * *}$ & 0.016 & $0.287^{* * * *}$ & $0.394 * * *$ & 0.894 \\
\hline $\begin{array}{l}\text { Negative emotions towards product } \\
\text { information -> RIs intentions }\end{array}$ & $-0.153 * * * *$ & 0.005 & 0.999 & 0.014 & $-0.104 * * * *$ & 0.042 & $-0.08 * *$ & $-0.09 *$ & 0.367 & $-0.065^{* *}$ & $-0.112^{* *}$ & 0.22 & -0.02 & $-0.093 * * *$ & 0.132 \\
\hline $\begin{array}{l}\text { Attitude towards financial risk -> RIs } \\
\text { intentions }\end{array}$ & $0.268 * * *$ & $0.219 * * *$ & 0.172 & $0.247 * * *$ & $0.254 * * *$ & 0.542 & $0.258^{* * * *}$ & $0.205^{* * * *}$ & 0.173 & $0.227 * * *$ & $0.259 * * *$ & 0.703 & $0.251^{* * *}$ & $0.239 * * *$ & 0.432 \\
\hline $\begin{array}{l}\text { Financial Satisfaction -> RIs } \\
\text { intentions }\end{array}$ & 0.037 & -0.039 & 0.072 & -0.003 & -0.003 & 0.496 & 0.024 & -0.033 & 0.13 & -0.007 & 0.024 & 0.702 & 0.021 & 0.013 & 0.454 \\
\hline $\begin{array}{l}\text { Positive emotions towards finance -> } \\
\text { RIs intentions }\end{array}$ & 0.008 & $-0.111^{*}$ & 0.068 & $-0.224^{* * *}$ & -0.026 & 0.97 & -0.028 & $-0.127 * *$ & 0.115 & $-0.102 * *$ & 0.097 & 0.985 & -0.076 & -0.066 & 0.541 \\
\hline $\begin{array}{l}\text { Negative emotions towards finance -> } \\
\text { RIs intentions }\end{array}$ & 0.061 & -0.071 & 0.018 & 0.016 & 0.017 & 0.507 & -0.043 & $0.126^{* *}$ & 0.99 & -0.014 & 0.024 & 0.738 & $-0.14 * *$ & 0.042 & 0.991 \\
\hline Self-esteem -> RIs intentions & 0.08 & -0.013 & 0.092 & $-0.127 *$ & 0.043 & 0.975 & 0.017 & 0.02 & 0.526 & 0.029 & -0.085 & 0.064 & -0.072 & 0.035 & 0.829 \\
\hline Sensation seeking -> RIs intentions & $0.104 * * *$ & $0.073^{*}$ & 0.28 & $0.169 * * *$ & 0.035 & 0.017 & $0.083^{* * *}$ & 0.066 & 0.378 & $0.073 * *$ & $0.141 * * *$ & 0.881 & $0.136 * * *$ & $0.062 * *$ & 0.103 \\
\hline $\begin{array}{l}\text { Positive emotions towards life -> RIs } \\
\text { intentions }\end{array}$ & $-0.085^{*}$ & -0.032 & 0.775 & 0.085 & $-0.073^{*}$ & 0.036 & -0.069 & -0.005 & 0.839 & -0.06 & 0.005 & 0.786 & -0.017 & -0.045 & 0.372 \\
\hline $\begin{array}{l}\text { Negative emotions towards life -> RIs } \\
\text { intentions }\end{array}$ & $0.124^{* *}$ & $0.089 * *$ & 0.278 & -0.017 & 0.085 & 0.838 & $0.128^{* * * *}$ & 0.041 & 0.133 & $0.12^{* * *}$ & 0.061 & 0.189 & $0.137^{*}$ & $0.098^{* *}$ & 0.283 \\
\hline
\end{tabular}


Appendix 4. Finance-related control variables

\begin{tabular}{|c|c|c|c|c|c|c|}
\hline \multirow[b]{2}{*}{ Path Relationships } & \multicolumn{3}{|c|}{ EXPERIENCE } & \multicolumn{3}{|c|}{ KNOWLEDGE } \\
\hline & Unexperienced & Experienced & $p$-value & High & Low & p-value \\
\hline Evaluation of product information $->$ RIs intentions & $0.288 * * *$ & $0.223 * * *$ & 0.168 & $0.257 * * *$ & $0.228 * * *$ & 0.661 \\
\hline Credibility of product information $->$ RIs intentions & 0.055 & $0.155 * * *$ & 0.947 & $0.094 *$ & $0.104 * * *$ & 0.443 \\
\hline Positive emotions towards product information -> RIs intentions & $0.294 * * *$ & $0.413 * * *$ & 0.942 & $0.447 * * *$ & $0.308^{* * * *}$ & 0.972 \\
\hline Negative emotions towards product information -> RIs intentions & $-0.114 * * *$ & -0.026 & 0.957 & 0.01 & $-0.127 * * *$ & 0.995 \\
\hline Attitude towards financial risk -> RIs intentions & $0.330 * * *$ & $0.183 * * *$ & 0.003 & $0.229 * * *$ & $0.256 * * *$ & 0.317 \\
\hline Financial Satisfaction $->$ RIs intentions & 0.015 & -0.034 & 0.169 & -0.028 & 0.015 & 0.215 \\
\hline Positive emotions towards finance -> RIs intentions & -0.093 & -0.076 & 0.583 & $-0.180 * * *$ & 0.021 & 0.007 \\
\hline Negative emotions towards finance -> RIs intentions & -0.013 & 0.067 & 0.905 & 0.004 & 0.025 & 0.356 \\
\hline Self-esteem -> RIs intentions & 0.033 & 0.008 & 0.345 & 0.01 & 0 & 0.563 \\
\hline Sensation seeking $\rightarrow>$ RIs intentions & $0.066^{*}$ & $0.067 * *$ & 0.507 & $0.082 * *$ & $0.073 * *$ & 0.569 \\
\hline Positive emotions towards life -> RIs intentions & -0.065 & -0.01 & 0.79 & 0.013 & -0.065 & 0.861 \\
\hline Negative emotions towards life -> RIs intentions & 0.083 & $0.072 * *$ & 0.389 & 0.078 & $0.101 * *$ & 0.354 \\
\hline
\end{tabular}




\section{Appendix 5. Table of applied measures}

\section{Scale and Items}

Watson, Clark and Tellegen (1988; 1994) PANAS - applied to all emotion scales (positive and negative)

Interested (positive)

Distressed (negative)

Excited (positive)

Upset (negative)

Strong (positive)

Guilty (negative)

Scared (negative)

Hostile (negative)

Enthusiastic (positive)

Proud (positive)

Irritable (negative)

Alert (positive)

Ashamed (negative)

Inspired (positive)

Nervous (negative)

Determined (positive)

Attentive (positive)

Jittery (negative)

Active (positive)

Afraid (negative)

Rosenberg (1965) adapted by Grable and Joo (2004) Self-esteem

I take a positive attitude toward myself.

I feel that I'm a person of worth, at least on an equal basis with others.

Ifeel that I have a number of good qualities.

I certainly feel useless at times.

I am able to do things as well as most other people.

On the whole, I am satisfied with myself.

\section{Arnett (1994) adapted by Grable and Joo (2004) Sensation Seeking}

It's fun and exciting to perform or speak before a group.

I would like to ride the roller coaster or other fast rides at an amusement park.

I would like to travel to places that are strange and far away.

\begin{tabular}{c}
\hline Baker and Churchill (1977) Evaluation of product information \\
Dull-Interesting \\
Unappealing-Appealing \\
Unimpressive-Impressive \\
Unattractive-Attractive \\
Uninformative-Informative \\
Confusing-Clear \\
Not eye catching-Eye catching \\
Ordinary-Distinctive \\
\hline Flanagin and Metzger (2000) Credibility of product information \\
Inaccurate-Accurate \\
Not trustworthy-Trustworthy \\
Biased-Not biased \\
Unbelievable-Believable \\
Incomplete-Complete \\
\hline Grable and Joo (2004) Financial Satisfaction \\
\hline Overall, how financially satisfied are you at this point of your life?
\end{tabular}

Suppose you are to sell all of your major possessions (including your home), turn all of your investments and other assets into cash, and pay all of your debts. Would you be in debt, break even, or have something left over? 
I would be interested to invest in the portfolio offered.

$I$ would be interested to receive more information from DeltaInvest regarding the portfolio offered.

I would be interested to book a session with an advisor from DeltaInvest regarding the portfolio offered.

I would recommend this portfolio to friends/family.

I would be interested to talk to someone I trust about the portfolio.

I would like to search for more information about the company DeltaInvest and the portfolio. 